\title{
Polityka społeczna i rozwój społeczny specjalnego regionu administracyjnego Hongkongu. Koncepcje i zasady organizacji świadczenia pomocy społecznej w Hongkongu (cz. 1)*
}

\author{
JEL Classification: I, I3, I38
}

Słowa kluczowe: polityka społeczna, świadczenia pomocy społecznej, Hongkong

Keywords: social policy, social welfare benefits, Hong Kong

\begin{abstract}
Abstrakt: Celem badań był opis aktualnego modelu polityki społecznej Hongkongu oraz wskazanie specyficznych czynników, które ukształtowały jego rozwój. Należy do nich doktryna konfucjanizmu oparta na założeniu postrzegania względnego ubóstwa i luki dochodowej części społeczeństwa jako koniecznego zła wynikającego z braku motywacji do pracy, która zapewnia dobrobyt. W modelu tym nie ma powszechnego w Europie ,rozdawnictwa socjalnego”, stąd wypływa często jego krytyka ze strony zwolenników „,państwa dobrobytu”. Wyniki przeprowadzonych badań zaprezentowano w dwóch częściach: Koncepcje i zasady organizacji świadczenia pomocy społecznej Hongkongu (cz. 1) oraz Pomoc finansowa z opieki społecznej - programy socjalne, czyli ochrony zdrowia, mieszkalnictwa, edukacji i zabezpieczenia społecznego. Wykazano w niej, że rząd Hongkongu podejmuje wiele działań, które odgrywają ważną rolę w promowaniu rozwoju społecznego, a jego zaangażowanie determinowane jest złożoną interakcją sił politycznych, społecznych i gospodarczych. Prezentowane badania oparte zostały na kwerendzie materiałów źródłowych rządu Hongkongu oraz pogłębionych wywiadach indywidualnych z jego mieszkańcami. Do weryfikacji wyników badań zastosowano metodę pogłębionego wywiadu indywidualnego (IDI), celem uzyskania szczegółowych opinii i informacji od wybranych mieszkańców Hongkongu na temat oceny i funkcjonowania systemu polityki społecznej oraz formułowanych wniosków. Przeprowadzono je w marcu i kwietniu 2019 roku z przedstawicielami mieszkańców i biznesmenów.
\end{abstract}

* Transkrypcja języka chińskiego została dokonana w systemie jyutping. Tłumaczenia z języka chińskiego autorki artykułu. 


\title{
Social policy and social development of the Hong Kong Special Administrative Region. Concepts and rules for the organization of social welfare in Hong Kong (Part 1)
}

\begin{abstract}
The aim of the research was to describe the current model of Hong Kong's social policy and to indicate specific factors that shaped its development. These include the doctrine of Confucianism based on the assumption of perceiving relative poverty and the income gap of a part of society as a necessary evil resulting from a lack of motivation for work that ensures well-being. In this model there is no general "social money wastefulness" as in Europe, hence its criticism often comes from supporters of the "welfare state." The results of the conducted research have been presented in two parts, namely: "Concepts and rules for the organization of social welfare in Hong Kong (Part 1)" and "Financial assistance from social welfare - social programs," that is, health, housing, education and social security. It has been proven that the Hong Kong government is undertaking a series of activities that play an important role in promoting social development, and its involvement is determined by the complex interaction of political, social and economic forces. The presented research was based on the source materials of the Hong Kong government and in-depth individual interviews with its residents.
\end{abstract}

\section{Wstęp}

Hongkong - obecnie Specjalny Region Administracyjny Chińskiej Republiki Ludowej (SRAChRL), w latach 1842-1997 będący pod okupacją brytyjską, zaliczany jest do grupy pięciu Azjatyckich Tygrysów będących najbardziej dynamicznie rozwijającymi się obszarami gospodarki światowej. Cechuje się jedną z najbardziej konkurencyjnych gospodarek na świecie, zaliczany do największych światowych centrów handlowo-finansowych z jednym z najbardziej wydatnych systemów finansowych, jak też rynków kapitałowych.

Do zbudowania potęgi gospodarczej Hongkongu przyczynił się wieloletni rozwój wymiany towarowej z ChRL oraz sukcesywnie zwiększający się jego udział w międzynarodowym obrocie handlowym. Sprzyjają temu uwarunkowania geograficzne, położenie nadmorskie (liczne porty morskie) i sąsiedztwo państw z wielomilionową ludnością, co stwarza chłonne rynki zbytu.

Hongkong na powierzchni $1104 \mathrm{~km}^{2}$ zamieszkuje 7,35 mln mieszkańców (dane za rok 2016), jednak jego produkt krajowy brutto jest ponad trzykrotnie większy od polskiego.

Sukcesy rozwoju gospodarczego Hongkongu budzą powszechne zainteresowanie opinii światowej, szczególnie europejskiej.

Od czasu przekazania Hongkongu Chińskiej Republice Ludowej (ChRL), które miało miejsce w 1997 r., Unia Europejska (UE) i jej państwa członkowskie uważnie obserwują zmiany polityczne i gospodarcze zachodzące w Specjalnym Regionie Administracyjnym Hongkong (SRAH)uwzględniając zasadę ,jeden kraj, dwa systemy”. UE respektuje politykę ,jednych Chin” oraz popiera zasadę ,jeden kraj, dwa systemy" i jej egzekwowanie ${ }^{1}$.

${ }^{1}$ Sprawozdanie dla Parlamentu Europejskiego i Rady. Specjalny Region Administracyjny Hongkong: sprawozdanie roczne za 2017 r., Bruksela, dnia 24 kwietnia 2018 roku, JOIN (2018) 7 final (8316/18 ur DGC 1B PL), s. 1.

Studenckie Prace Prawnicze, Administratywistyczne

i Ekonomiczne 30, 2019

(C) for this edition by CNS 
Krytycznie natomiast odnosi się do systemu polityki społecznej, znacznie odbiegającego od standardów europejskich. We wnioskach z publikowanych w Europie badań funkcjonowania systemu społeczno-gospodarczego Hongkongu nie uwzględnienia się czynników historycznych (specyfiki wynikającej z okresu kolonialnego), kulturowych (model życia oparty na innych przesłankach etycznych, moralnych i religijnych), gdyż przeważa przekonanie o wyższości własnego systemu gospodarczego i politycznego, który winien być wzorem do naśladowania dla innych. O przedmiotowym traktowaniu Hongkongu może świadczyć samo sformułowanie „Od czasu przekazania Hongkongu Chińskiej Republice Ludowej (ChRL)", które w rzeczywistości po okresie angielskiego kolonializmu było powrotem do integralnego - suwerennego - obszaru Chin.

W analizach polityki społecznej Hongkongu podkreśla się takie niedogodności, jak przykładowo, że jedna piąta $(1,35 \mathrm{mln} \text { w } 2016 \text { roku })^{2}$ jego mieszkańców żyje na poziomie ubóstwa. Nie uwzględnia się natomiast działań rządu, czyli darmowej opieki społecznej oraz zapomóg dla osób starszych, co powoduje, że liczba ubogich Hongkończyków w tym roku była mniejsza niż milion. Podobnie wskazuje się na rosnące koszty życia i ceny nieruchomości w Hongkongu, na co znacznie wpływa coroczny napływ zarówno ubogich imigrantów zarobkowych, jak i bogatych inwestorów z Chin kontynentalnych wykupujących nieruchomości.

W cytowanym sprawozdaniu Komisji Europejskiej sytuacja na rynku mieszkaniowym i nieruchomości oceniana jest następująco:

Dzięki niskim stopom procentowym, nadmiarowej płynności i dużemu popytowi ze strony inwestorów obroty na rynku nieruchomości w 2017 r. osiągnęły rekordowe poziomy. W porównaniu z 2016 r. szczególnie duży wzrost cen (o 16,7\%) odnotowano w przypadku prywatnych nieruchomości mieszkalnych. Tym samym Hongkong stał się najdroższym rynkiem mieszkaniowym świata. To w skali globalnej najmniej przystępny cenowo ośrodek miejski dla nabywców nieruchomości. Aby zapewnić większą przystępność cenową mieszkań dla nowych nabywców, mieszkania w nowych budynkach są średnio coraz mniejsze. Ponieważ ceny zakupu i wynajmu nieruchomości mieszkaniowych nadal rosły, popyt na lokale socjalne był rekordowo wysoki ${ }^{3}$.

Krytykuje się również, że pomimo nadwyżki budżetowej w wysokości 3,7\% PKB w latach 2016-2017 oraz szacunkowej rezerwy na lata 2017-2018 w wysokości 37\% PKB władze Hongkongu nie podejmują długookresowych działań (tylko jednorazowe) dotyczących na przykład ulg i zwolnień oraz zwiększenia wydatków na opiekę nad osobami starszymi. Natomiast podkreśla się, że „dzięki sprzyjającej sytuacji budżetowej rząd mógł również zmniejszyć obciążenie podatkowe przedsiębiorstw"4.

Przeprowadzona analiza systemu społeczno-gospodarczego Hongkongu wskazuje, że nie jest on w pełni gospodarką wolnorynkową mimo przyjętej ekonomicznej doktryny leseferyzmu, gdyż w wielu obszarach Hongkong ma wysoce rozwi-

2 Ibidem, s. 13.

3 Ibidem, s. 11.

4 Ibidem, s. 12.

Studenckie Prace Prawnicze, Administratywistyczne

i Ekonomiczne 30, 2019

(C) for this edition by CNS 
niętą politykę społeczną, która w znacznym stopniu przyczynia się do poprawy jakości życia jego mieszkańców. W badaniach skupiono się na jednym z obszarów systemu społeczno-gospodarczego, czyli polityce społecznej, wybierając do analizy spośród licznych pakietów socjalnych usługi opieki społecznej.

Należy podkreślić, że polityka społeczna w Hongkongu, tak jak cały system społeczno-gospodarczy, jest determinowana doktryną konfucjanizmu oraz celami strategicznymi określonymi przez ustawę zasadniczą Hongkongu SRAH ChRL w rozdziale VI. Edukacja, nauka, kultura, sport, religia, praca i opieka społeczna. Ponadto musi ona uwzględniać zawarte w niej uwarunkowania funkcjonowania systemu gospodarczego, czyli rozdział V. Gospodarka - sekcja 1. Finanse publiczne, polityka monetarna, rzemiosto, przemyst $i$ handel zakładające między innymi niskie opodatkowanie i uzyskanie nadwyżki finansowej ${ }^{5}$.

\section{Instytucje rządu Hongkongu odpowiedzialne za realizację polityki społecznej}

Rząd Hongkongu systematycznie i skutecznie angażuje się w pomoc potrzebującym osobom i rodzinom. Obszar działania i rozległość usług opieki społecznej w Hongkongu rozwijały się w ciągu lat, a łączne powtarzające się wydatki rządowe przeznaczane na pomoc (opiekę) społeczną systematycznie wzrastały, przykładowo w latach 2006-2016 około 80\%, natomiast w latach 2007-2017 wzrost ten wyniósł już 95\% ${ }^{6}$.

Za podstawowe zabezpieczenie społeczne w Hongkongu odpowiedzialny jest Urząd Pracy i Opieki Społecznej (勞工及福利局, UPOS), który formułuje politykę opieki społecznej i nadzoruje jej wdrażanie przez Departament Pomocy Społecznej (社會福利署, DPS), Biuro do spraw Zasiłku Rodzinnego dla Rodziny Pracującej (在職家庭津貼辦事處, BZRRP) i Studencką Agencję Pomocy Finansowej (在職家庭及學生資助事務處, SAPF).

W sprawach polityki socjalnej doradzają rządowi: Komitet Doradczy do spraw Opieki Społecznej (社會福利諮詢委員會, KDOS), Komisja do spraw Seniora ( 安老事務委員會, KS), Komitet Doradczy do spraw Rehabilitacji (康復諮詢委員 會, KDR) i Komisja do spraw Kobiet (婦女事務委員會, KK).

Misją Urzędu Pracy i Opieki Społecznej jest ochrona praw pracowników, a także poprawa dobrobytu słabszych grup społecznych (żyjących w złych warunkach). Urząd jest wspierany przez Departament Pracy (勞工處, DP) i Departament Opieki Społecznej (社會福利署, DOS), z którymi opracowuje i wdraża różnie ukierunkowane inicjatywy dotyczące polityki zatrudnienia i opieki społecznej.

5 Basic Law, https://www.basiclaw.gov.hk/en/basiclawtext/index.html (dostęp: 24.04.2019).

6 社會福利, 香港年報, (se5 wui2 fuk1 lei6, hoeng1 gong2 nin4 bou3) 2017, s. 156; 社會福利, 香港年報 (se5 wui2 fuk1 lei6, hoeng1 gong2 nin4 bou3) 2018, s. 155 .

Studenckie Prace Prawnicze, Administratywistyczne

i Ekonomiczne 30, 2019

(C) for this edition by CNS 
Do głównych zadań wymienionych instytucji w sektorze pracy należy promowanie zatrudnienia, utrzymanie harmonijnych relacji pracodawca-pracownik (stosunków pracy), ochrona praw pracowników oraz wzmacnianie bezpieczeństwa i zdrowia w pracy. W obszarze opieki społecznej zobowiązane są wdrażać politykę mającą na celu budowanie troskliwej i spójnej społeczności (harmonijnego społeczeństwa), zmniejszenia ubóstwa, opieki nad osobami starszymi, pomocy słabszym, wsparcia dla rodzin znajdujących się w niekorzystnej sytuacji i potrzebujących, a także promowania samodzielności poprzez odpowiednie środki wsparcia.

Wspierają one również prawa kobiet w Hongkongu oraz nadzorują wdrażanie kwestii politycznych związanych z planowaniem siły roboczej, szkoleniem zawodowym i przekwalifikowaniem.

Zadaniem Urzędu Pracy i Opieki Społecznej jest także rozwijanie bliższej współpracy z sektorem biznesu, organizacjami pozarządowymi i społeczeństwem obywatelskim? ${ }^{7}$.

Mimo że Hongkong nie jest państwem opiekuńczym, to jednak mieszkańcy zwracają szczególną uwagę na dobrobyt ludzi. Społeczeństwo oczekuje, że rząd pomoże osobom ubogim utrzymać podstawowy standard życia. W 1992 roku Departament Opieki Społecznej wydał $7 \mathrm{mld}$ HKD, a pięć lat później wydatki wzrosły już do 20,6 mld $\mathrm{HKD}^{8}$.

Od powrotu Hongkongu do Chin (1 lipca 1997 roku) obserwuje się dynamiczny wzrost wydatków i wsparcia przeznaczonego na pomoc społeczną dla osób w niekorzystnej sytuacji finansowej, które zwiększały się w każdym następnym roku (por. tabela 1). W tabeli można zaobserwować, że sukcesywnie pojawiają się nowe instytucje i formy finansowania przeznaczone na pomoc socjalną.

W latach 2018-2019 całkowity budżet wydatków Departamentu Opieki Społecznej wyniósł 84,2 mld HKD. Spośród nich 60,2 mld HKD przeznaczono na pomoc finansową (wydatki socjalne), 16,8 mld HKD na powtarzające się dotacje dla organizacji pozarządowych, 2,9 mld HKD na inne usługi socjalne i 4,3 mld HKD na wydatki departamentalne. Jednym ze źródeł finansowania jednorazowych wydatków dla organizacji pozarządowych jest Fundusz Loterii (獎券基金). W latach 2018-2019 szacunkowe wydatki Funduszu Loterii wyniosły 3 mld HKD ${ }^{9}$.

Dążenia rządu Hongkongu do poprawy poziomu życia mieszkańców potwierdzają wydatki rządu na opiekę społeczną w latach 2010-2017, szczególnie jeśli się je porówna z okresem kryzysu finansowego w latach 2007-2009.

7 香港特別行政區政府,勞工及福利局,主頁, 歡迎辭, (hoeng1 gong2 dak6 bit6 hang4 zing3 keoil zing3 fu2, lou4 gung1 kap6 fuk1 lei6 guk6, zyu2 jip6, fun1 jing4 ci4), https://www.lwb.gov. hk/chi/home/index.htm (dostęp: 6.04.2019).

${ }^{8}$ Dane z Departamentu Opieki Społecznej.

9 社會福利, 香港政府一站通, 2018年4月, s. 1, (se5 wui2 fuk1 lei6, hoeng1 gong2 zing3 fu2 jat1 zaam6 tung1, 2018 nin4 4 jyut6, s. 1). 
Tabela 1. Wydatki rządu Hongkongu na opiekę społeczną w latach 1997-2019

\begin{tabular}{|c|c|c|c|c|c|}
\hline Lata & $\begin{array}{c}\text { Lączne wydatki } \\
\text { powtarzalne } \\
\text { Departamentu } \\
\text { Opieki } \\
\text { Społecznej } \\
\text { [HKD] }\end{array}$ & $\begin{array}{l}\text { Pomoc } \\
\text { finansowa }\end{array}$ & $\mid \begin{array}{c}\text { Powtarzające się } \\
\text { subwencje dla } \\
\text { organizacji } \\
\text { pozarządowych } \\
\text { (NGO) }\end{array}$ & $\begin{array}{l}\text { Inne płatności } \\
\text { na usługi } \\
\text { socjalne/ } \\
\text { *na wynajem } \\
\text { usług/ } \\
\text { **usługi } \\
\text { kontraktowe }\end{array}$ & $\begin{array}{c}\text { Wydatki } \\
\text { departamentów/ } \\
\text { *usługi świad- } \\
\text { czone przez } \\
\text { Departament } \\
\text { Opieki } \\
\text { Społecznej }\end{array}$ \\
\hline 2018-2019 & $84,2 \mathrm{mld}$ & $\begin{array}{l}\text { 60,2 mld HKD } \\
\quad(71,5 \%)\end{array}$ & $\begin{array}{l}16,8 \text { mld HKD } \\
(20 \%)\end{array}$ & $\begin{array}{l}2,9 \text { mld HKD } \\
(3,4 \%)\end{array}$ & $\begin{array}{l}4,3 \text { mld HKD } \\
(5,1 \%)\end{array}$ \\
\hline 2017-2018 & $65,8 \mathrm{mld}$ & b.d. & b.d. & b.d. & b.d. \\
\hline 2016-2017 & $61,5 \mathrm{mld}$ & $\begin{array}{c}41,7 \text { mld HKD } \\
(67,8 \%)\end{array}$ & $\begin{array}{c}14,5 \text { mld HKD } \\
(23,6 \%)\end{array}$ & $\begin{array}{l}1,9 \text { mld HKD } \\
(3,1 \%)\end{array}$ & $\begin{array}{l}\text { 3,4 mld HKD } \\
(5,5 \%)\end{array}$ \\
\hline 2015-2016 & $57,1 \mathrm{mld}$ & $\begin{array}{c}38,8 \text { mld HKD } \\
(67,9 \%)\end{array}$ & $\begin{array}{l}13,4 \text { mld HKD } \\
(23,5 \%)\end{array}$ & $\begin{array}{c}1,7 \text { mld HKD } \\
(3 \%)\end{array}$ & $\begin{array}{l}3,2 \text { mld HKD } \\
(5,6 \%)\end{array}$ \\
\hline 2014-2015 & $53,5 \mathrm{mld}$ & $\begin{array}{c}36,8 \text { mld } \\
\text { HKD68,8\% }\end{array}$ & $\begin{array}{c}12,3 \text { mld HKD } \\
(23 \%)\end{array}$ & $\begin{array}{c}1,4 \text { mld HKD } \\
(2,6 \%)\end{array}$ & $\begin{array}{l}3 \text { mld HKD } \\
(5,6 \%)\end{array}$ \\
\hline 2013-2014 & $51 \mathrm{mld}$ & $\begin{array}{l}36,1 \text { mld HKD } \\
\quad(70,8 \%)\end{array}$ & $\begin{array}{l}10,9 \text { mld HKD } \\
(21,4 \%)\end{array}$ & $\begin{array}{c}1,2 \text { mld HKD } \\
(2,3 \%)\end{array}$ & $\begin{array}{l}2,8 \text { mld HKD } \\
(5,5 \%)\end{array}$ \\
\hline $\begin{array}{c}2012- \\
2013^{* * *}\end{array}$ & 42,4 mld & $\begin{array}{c}28,5 \text { mld HKD } \\
(67,2 \%)\end{array}$ & $\begin{array}{l}10,2 \text { mld HKD } \\
(24,1 \%)\end{array}$ & $\begin{array}{l}\text { 1,1 mld HKD } \\
(2,6 \%)\end{array}$ & $\begin{array}{l}\text { 2,6 mld HKD } \\
(6,1 \%)\end{array}$ \\
\hline 2012 & $41,7 \mathrm{mld}$ & $\begin{array}{c}28,2 \text { mld HKD } \\
(67,7 \%)\end{array}$ & $\begin{array}{l}9,9 \text { mld HKD } \\
(23,7 \%)\end{array}$ & $\begin{array}{l}1 \text { mld HKD } \\
(2,4 \%)^{*}\end{array}$ & $\begin{array}{l}\text { 2,6 mld HKD } \\
(6,2 \%)\end{array}$ \\
\hline 2011 & $39,3 \mathrm{mld}$ & $\begin{array}{c}26,8 \text { mld HKD } \\
(68,2 \%)\end{array}$ & $\begin{array}{c}9,2 \text { mld HKD } \\
(23,4 \%)\end{array}$ & $\begin{array}{l}0,9 \text { mld HKD } \\
(2,3 \%)^{*}\end{array}$ & $\begin{array}{c}2,4 \text { mld HKD } \\
(6,1 \%)\end{array}$ \\
\hline 2010 & $37,3 \mathrm{mld}$ & $\begin{array}{l}25,7 \text { mld HKD } \\
(68,9 \%)\end{array}$ & $\begin{array}{l}8,5 \text { mld HKD } \\
(22,8 \%)\end{array}$ & $\begin{array}{l}0,8 \text { mld HKD } \\
(2,1 \%)^{*}\end{array}$ & $\begin{array}{c}2,3 \text { mld HKD } \\
(6,2 \%)\end{array}$ \\
\hline 2009 & 39 mld & $\begin{array}{l}27,7 \text { mld HKD } \\
(71,1 \%)\end{array}$ & $\begin{array}{l}8,3 \text { mld HKD } \\
(21,2 \%)\end{array}$ & $\begin{array}{l}0,7 \text { mld HKD } \\
(1,8 \%)^{*}\end{array}$ & $\begin{array}{l}2,3 \text { mld HKD } \\
(5,9 \%)\end{array}$ \\
\hline 2008 & $37,6 \mathrm{mld}$ & $\begin{array}{l}26,9 \text { mld HKD } \\
(71,6 \%)\end{array}$ & $\begin{array}{l}\text { 7,8 mld HKD } \\
(20,7 \%)\end{array}$ & $\begin{array}{l}0,6 \text { mld HKD } \\
(1,6 \%)^{*}\end{array}$ & $\begin{array}{l}2,3 \text { mld HKD } \\
(6,1 \%)\end{array}$ \\
\hline 2007 & $33,8 \mathrm{mld}$ & $\begin{array}{c}24,2 \text { mld HKD } \\
(71,6 \%)\end{array}$ & $\begin{array}{c}6,8 \text { mld } \\
\operatorname{HKD}(20,1 \%)\end{array}$ & $\begin{array}{c}500 \text { mln HKD } \\
(1,5 \%)^{*}\end{array}$ & $\begin{array}{l}2,3 \text { mld HKD } \\
(6,8 \%)\end{array}$ \\
\hline 2006 & $32,2 \mathrm{mld}$ & $\begin{array}{c}23,1 \text { mld HKD } \\
(71,7 \%)\end{array}$ & $\begin{array}{c}6,4 \text { mld HKD } \\
(19,9 \%)\end{array}$ & $\begin{array}{c}500 \text { mln HKD } \\
(1,6 \%)^{*}\end{array}$ & $\begin{array}{c}2,2 \text { mld HKD } \\
(6,8 \%)\end{array}$ \\
\hline 2005 & $32,2 \mathrm{mld}$ & $\begin{array}{c}23,4 \text { mld HKD } \\
(72,7 \%)\end{array}$ & $\begin{array}{c}6,4 \text { mld HKD } \\
(19,9 \%)\end{array}$ & $\begin{array}{c}500 \text { mln HKD } \\
(1,5 \%)^{*}\end{array}$ & $\begin{array}{l}1,9 \text { mld HKD } \\
(5,9 \%)\end{array}$ \\
\hline 2004 & $32,4 \mathrm{mld}$ & $\begin{array}{l}23,3 \text { mld HKD } \\
\quad(71,9 \%)\end{array}$ & $\begin{array}{l}\text { 6,6 mld HKD } \\
(20,4 \%)\end{array}$ & $\begin{array}{l}0,5 \text { mld HKD } \\
(1,5 \%)^{*}\end{array}$ & $\begin{array}{c}2 \text { mld HKD } \\
(6,2 \%)\end{array}$ \\
\hline 2003 & $32,4 \mathrm{mld}$ & $\begin{array}{l}22,9 \text { mld HKD } \\
\quad(70,7 \%)\end{array}$ & 6,9 mld $(21,3 \%)$ & $\begin{array}{c}0,5 \text { mld HKD } \\
(1,5 \%)^{* *}\end{array}$ & $\begin{array}{l}\text { 2,1 mld HKD } \\
(6,5 \%)^{*}\end{array}$ \\
\hline
\end{tabular}




\begin{tabular}{|c|c|c|c|c|c|}
\hline 2002 & $31 \mathrm{mld}$ & $\begin{array}{c}21,5 \mathrm{mld} \mathrm{HKD} \\
(69,3 \%)\end{array}$ & $\begin{array}{c}6,9 \text { mld HKD } \\
(22,3 \%)\end{array}$ & $\begin{array}{c}0,4 \mathrm{mld} \mathrm{HKD} \\
(1,3 \%)^{* *}\end{array}$ & $\begin{array}{c}2,2 \text { mld HKD } \\
(7,1 \%)^{*}\end{array}$ \\
\hline 2001 & $29,7 \mathrm{mld}$ & $\begin{array}{c}20,5 \mathrm{mld} \mathrm{HKD} \\
(69 \%)\end{array}$ & $\begin{array}{c}7,2 \mathrm{mld} \mathrm{HKD} \\
(24 \%)\end{array}$ & - & $\begin{array}{c}2 \mathrm{mld} \mathrm{HKD} \\
(6,7 \%)\end{array}$ \\
\hline 2000 & $29,5 \mathrm{mld}$ & - & - & - & - \\
\hline 1999 & $27,9 \mathrm{mld}$ & - & - & - & - \\
\hline 1998 & $25,5 \mathrm{mld}$ & - & - & - & - \\
\hline 1997 & $20,6 \mathrm{mld}$ & - & - & - & - \\
\hline
\end{tabular}

*** Od 2013 roku nastąpiła zmiana obliczania całkowitych wydatków cyklicznych Departamentu Opieki Społecznej przeznaczonych na opiekę społeczną, zamiast ich obliczania za dany rok kalendarzowy przyjęto prezentację danych za rok budżetowy, który rozpoczyna się od 1 kwietnia danego roku do 31 marca roku następnego.

Źródło: Opracowanie własne na podstawie 社會福利, 香港年報 za lata 1997-2017; 社會福利, 香港政府一 站通, 2018年4月, s. 1. (se5 wui2 fuk1 lei6, hoeng1 gong2 nin4 bou3 za lata 1997-2017; se5 wui2 fuk1 lei6, hoeng1 gong2 zing3 fu2 jat1 zaam6 tung1, 2018 nin4 4 jyut6, s. 1).

Dział Pomocy Rodzinie Pracującej i Studenckiej Pomocy Finansowej zobowiązany jest do udzielenia specjalnych dotacji pomocy finansowej potrzebującym rodzinom w Hongkongu, celem wsparcia edukacji dzieci i młodzieży lub zachęcania członków gospodarstwa domowego do aktywnego zatrudnienia, jak też kontynuowania podnoszenia kwalifikacji w okresie pracy, aby z niej nie rezygnowali.

Poprzez wiele programów pomocy finansowej dla studentów, obejmujących uczniów od poziomu edukacji przedszkolnej do kształcenia pomaturalnego (policealnego), tworzy on gwarancje, aby żadnemu uczniowi w Hongkongu nie odmówiono dostępu do edukacji z powodu braku środków finansowych. Oferuje również wiele stypendiów i programów nagród, aby zachęcać uczniów do aktywnej nauki oraz osiągania dobrych wyników, a studentów do osiągania doskonałości w studiach akademickich poprzez liczne programy stypendialne i nagrody za osiągnięte wyniki naukowe.

Odpowiada także za wdrożenie Programu zasiłków dla osób pracujących (職家 庭津貼(職津), PZOP) oraz Indywidualnego programu dotacji na dojazd do pracy (勵就業交通津貼(個人交津), IPDDP) dla osób fizycznych. Pierwszy z nich ma na celu zachęcić do samodzielności i tworzyć warunki do łagodzenia ubóstwa międzypokoleniowego, drugi z kolei pomaga osobom pracującym o niskich dochodach obniżyć koszty podróży do i z miejsca pracy oraz zachęca ich do podjęcia lub pozostania $\mathrm{w}$ pracy ${ }^{10}$.

10 在職家庭及學生資助事務處, 主頁, 歡迎辭, (zoi6 zik1 gaa1 ting4 kap6 hok6 saang1 zi1 zo6 si6 mou6 cyu3, zyu2 jip6, fun1 jing4 ci4), https://www.wfsfaa.gov.hk/tc/index.htm (dostęp: 6.04.2019).

Studenckie Prace Prawnicze, Administratywistyczne

i Ekonomiczne 30, 2019

(C) for this edition by CNS 


\section{Organy doradcze}

\subsection{Komitet Doradczy do spraw Opieki Społecznej}

Komitet Doradczy do spraw Opieki Społecznej okresowo dokonuje przeglądu świadczonych usług pomocy społecznej i doradza rządowi we wszystkich kwestiach dotyczących polityki pomocy społecznej. W 2016 roku Komitet zaproponował doradztwo $\mathrm{w}$ sprawie ujętych w polityce inicjatyw społecznych oraz zgłosił sugestie dotyczące ich priorytetu w zakresie „dobrostanu” w latach 2017-2018, realizowanego przez sektor opieki społecznej $\mathrm{i}$ inne organy doradcze ${ }^{11}$.

W 2017 roku Komitet doradzał rządowi w sprawie inicjatyw w zakresie pomocy społecznej ogłoszonych w styczniowych i październikowych założeniach polityki oraz przekazał sugestie dotyczące priorytetów w zakresie dobrobytu w latach 20182019, wykonywanych przez sektor opieki społecznej i inne organy doradcze ${ }^{12}$.

\subsection{Komisja do spraw Seniora}

W 1997 roku Dyrektor Naczelny Rządu Specjalnego Regionu Administracyjnego Hongkongu uczynił opiekę nad osobami starszymi strategicznym celem rządu SRAH mającym poprawić jakość życia starszych ludzi, zapewniając im poczucie bezpieczeństwa, przynależności oraz zdrowia i godności.

W tym samym roku powołano Komisję do spraw Seniora, której głównym zadaniem jest zapewnienie doradztwa rządowi w zakresie formułowania kompleksowej polityki dotyczącej opieki nad osobami starszymi oraz usług dla osób starszych. Do jej zadań należy promowanie aktywnego starzenia się, a także doradzanie, w jaki sposób poprawić długoterminowe usługi opiekuńcze. Członkowie Komisji są mianowani przez Dyrektora Naczelnego Rządu SRAH, są nimi specjaliści, naukowcy i liderzy społeczności (okręgów) zaangażowani w usługi dla osób starszych i inne sektory.

Zakres zadań statutowych Komisji jest bardzo szeroki. Należy do nich między innymi:

— doradzanie rządowi w zakresie formułowania kompleksowej polityki wobec osób starszych, w tym kwestii związanych z potrzebami osób starszych w obszarach opieki, mieszkalnictwa, bezpieczeństwa finansowego, opieki zdrowotnej i potrzebami medycznymi, psychologicznymi, zatrudnieniem i rekreacją;

— koordynowanie planowania i rozwoju różnych programów i usług dla osób starszych oraz zalecanie rządowi priorytetów do realizacji, uwzględniając zasoby ludzkie (siłę roboczą), finansowe i inne dostępne zasoby;

11 社會福利, 香港年報, (se5 wui2 fuk1 lei6, hoeng1 gong2 nin4 bou3) 2017, op. cit., s. 166.

12 社會福利, 香港年報, (se5 wui2 fuk1 lei6, hoeng1 gong2 nin4 bou3) 2018, op. cit., s. 164. 
- monitorowanie wdrażania różnych polityk i programów dotyczących osób w podeszłym wieku i przedstawianie zaleceń rządowi, aby zapewnić osiągnięcie wyznaczonych celów ${ }^{13}$.

Komisja badała możliwość wprowadzenia Programu kuponów (bonów) na usługi opieki domowej oraz sformułowania Planu programu dla osób w podeszłym wieku, który przedstawiła rządowi w czerwcu 2017 roku. Zawierał on zalecenia dotyczące przyszłego rozwoju usług dla osób starszych, koniecznych w sytuacji starzenia się społeczeństwa.

Do sukcesu jej działań należy zaliczyć okoliczność, że w roku szkolnym 20162017 funkcjonowało w ramach Programu Akademii Seniora około 130 akademii seniora w szkołach podstawowych, średnich i wyższych, prowadzonego wspólnie przez Komisję i rząd ${ }^{14}$.

\subsection{Komisja do spraw Kobiet}

Instytucja Komisji do spraw Kobiet ustanowiona została przez rząd Hongkongu w styczniu 2001 roku jako centralny organ wysokiego szczebla. Utworzona przez Dyrektora Naczelnego Rządu Komisja ma dokonywać oceny sytuacji życiowej kobiet, jest też odpowiedzialna za formułowanie długoterminowych celów i strategii w zakresie rozwoju i awansu kobiet, aby zapewnić kobietom możliwości rozwijania swoich zdolności zawodowych umożliwiających awans ${ }^{15}$. Komisja w ramach swoich obowiązków statutowych:

- doradza rządowi w opracowaniu długoterminowych priorytetów i strategii związanych z rozwojem i awansem kobiet, a także w zakresie integracji polityk i inicjatyw dotyczących kobiet, które wchodzą w zakres różnych „,biur politycznych", aby zapewnić uwzględnianie ich praw przy formułowaniu polityki rządu;

— w świetle potrzeb kobiet poddaje przeglądowi usługi świadczone przez agencje rządowe i pozarządowe, identyfikuje priorytetowe obszary działania i monitoruje rozwój nowych lub ulepszania istniejących usług;

— inicjuje i przeprowadza niezależne badania naukowe dotyczące problemów kobiet oraz organizuje działania edukacyjne i promocyjne;

- nawiązuje, rozwija oraz utrzymuje kontakty z lokalnymi i międzynarodowymi organizacjami kobiet, a także agencjami usługowymi w celu dzielenia się doświadczeniami oraz poprawy komunikacji i zrozumienia ${ }^{16}$.

13 簡介, 安老事務委員會, (gaan2 gaai3, ngon1 lou5 si6 mou6 wai2 jyun4 wui2), https://www. elderlycommission.gov.hk/cn/About_Us/Introduction.html (dostęp: 2.04.2014).

14 社會福利, 香港年報, 2017, op. cit., s. 166; 社會福利, 香港年報, 2018, op. cit., s. 164 (se5 wui2 fuk1 lei6, hoeng1 gong2 nin4 bou3, 2017, s. 166; se5 wui2 fuk1 lei6, hoeng1 gong2 nin4 bou3, 2018, s. 164).

15 簡介, 婦女事務委員會, (gaan2 gaai3, fu5 neoi5 si6 mou6 wai2 jyun4 wui2), https://www. women.gov.hk/tc/aboutus/introduction.html (dostęp: 2.04.2019).

16 使命及職權範圍, 婦女事務委員會, (sai2 ming6 kap6 zik1 kyun4 faan6 wai4, fu5 neoi5 si6 mou6 wai2 jyun4 wui2), https://www.women.gov.hk/tc/aboutus/mission.html (dostęp: 2.04.2019). 
Celem Komisji do spraw Kobiet jest umożliwienie kobietom mieszkającym w Hongkongu pełnego urzeczywistnienia ich właściwego statusu, praw i możliwości we wszystkich aspektach życia poprzez zapewnienie sprzyjających warunków, wzmocnienie pozycji kobiet i udział w edukacji publicznej. Odgrywa również strategiczną rolę w obronie praw kobiet, inspirowaniu nowego myślenia i katalizowaniu zmian oraz mobilizowaniu zasobów społeczności ${ }^{17}$.

Komisja przyjęła trójetapową strategię działania: zapewnienie sprzyjającego otoczenia (środowiska), wzmocnienie pozycji kobiet poprzez zwiększanie zdolności oraz edukację publiczną. Utworzyła cztery grupy robocze w celu opracowania i nadzorowania (monitorowania) pracy w czterech strategicznych obszarach, to jest Tworzenie sprzyjającego środowiska (締造有利環境), Wzmacnianie umiejętności i szkolenia kobiet (增強婦女能力及培訓), Współpracy i promocji (協作 及推廣), Zdrowia i wsparcia (健康及支援 $)^{18}$.

Komisja, realizując swoje zadania statutowe, doradza rządowi w opracowywaniu odpowiednich polityk i inicjatyw, identyfikuje priorytetowe obszary działania, angażuje się w niezależne dochodzenia i badania naukowe oraz utrzymuje bliskie kontakty z lokalnymi i międzynarodowymi grupami kobiet i agencjami usługowymi.

Odgrywa również ważną rolę, pomagając rządowi wdrażać Konwencję w sprawie likwidacji wszelkich form dyskryminacji kobiet oraz Pekińską Platformę Działania.

Spotyka się ona regularnie na zwoływanych specjalnych naradach w celu omówienia aktualnych zagadnień, a także organizuje warsztaty, spotkania (konferencje) i sesje z zamiarem omówienia konkretnych spraw z grupami kobiet i organizacjami pozarządowymi ${ }^{19}$.

Komisja i rząd przygotowują program pilotażowy, który ma zachęcić organizacje pozarządowe zajmujące się pomocą społeczną do dostosowania listy kontrolnej włączającej problematykę płci, przyjętej przez rząd, oraz uwzględniania problematyki płci podczas formułowania polityk i programów.

Pod koniec 2016 roku utworzono sieć punktów kontaktowych do spraw płci dla spółek giełdowych w celu podniesienia świadomości kwestii związanych z płcią w środowisku biznesowym. Uzupełniła ona wcześniej utworzoną podobną sieć między biurami rządowymi i departamentami, radami okręgowymi i organizacjami pozarządowymi zajmującymi się pomocą społeczną ${ }^{20}$.

Lista kontrolna Komisji dotycząca problematyki płci jest analitycznym narzędziem, które ma pomóc rządowi w sposób systematyczny włączać potrzeby i per-

17 Ibidem, 社會福利, 香港年報, (se5 wui2 fuk1 lei6, hoeng1 gong2 nin4 bou3) 2017, op. cit., s. 166.

18 簡介, 婦女事務委員會, (gaan2 gaai3, fu5 neoi5 si6 mou6 wai2 jyun4 wui2), op. cit.

19 Ibidem.

20 社會福利, 香港年報, (se5 wui2 fuk1 lei6, hoeng1 gong2 nin4 bou3) 2017, op. cit., s. 166. 
spektywy płci do formułowania polityki i opracowywania programów. Wszystkie biura i departamenty mają obowiązek odwołać się do listy kontrolnej i stosować uwzględnianie problematyki płci podczas formułowania głównych polityk i inicjatyw. Rząd zapewnia również szkolenia urzędnikom służby cywilnej w kwestiach płci.

W celu promowania problematyki płci w różnych sektorach gospodarki Komisja prowadzi sieć punktów centralnych, które mają ułatwić kontakty należących do nich organizacji oraz pomóc w podnoszeniu świadomości na temat kwestii płci i zachęcać do korzystania z listy kontrolnej w pracy. Sieć obejmuje 75 biur i departamentów, 120 organizacji pozarządowych, 18 rad okręgowych i 168 spółek giełdowych $^{21}$.

Komisja podjęła wiele działań wspierających pozycję kobiet w społeczeństwie, opracowując między innymi Program budowania zdolności produkcyjnych, którego celem jest zwiększenie pewności siebie kobiet, umiejętności uczenia się i umiejętności życiowych, jak również Program finansowania na rzecz rozwoju kobiet, zapewniający finansowanie działalności organizacjom kobiecym i pozarządowym na poziomie regionalnym i okręgowym ${ }^{22}$.

\subsection{Komitet Doradczy do spraw Rehabilitacji}

Komitet Doradczy do spraw Rehabilitacji (康復諮詢委員會) jest głównym organem doradczym rządu w zakresie dobrostanu osób niepełnosprawnych oraz opracowywania i wdrażania polityki i usług rehabilitacyjnych. Pomaga rządowi promować i monitorować wdrażanie Konwencji Narodów Zjednoczonych o prawach osób niepełnosprawnych. Współpracuje też z radami okręgowymi oraz sektorami biznesu i opieki społecznej w celu promowania możliwości pracy osób niepełnosprawnych oraz usług wsparcia zatrudnienia świadczonych przez departamenty rządowe i organizacje rehabilitacyjne dla takich osób.

Komitet koordynuje wdrażanie publicznych programów edukacyjnych dotyczących rehabilitacji. W 2017 roku rząd i organizacje pozarządowe zorganizowały 43 (w 2016 roku - 45) publicznych programów edukacyjnych w celu promowania idei cytowanej konwencji ONZ oraz podjęły współpracę międzysektorową w budowaniu społeczeństwa opartego na zasadzie równości i integracji. Komitet promował także Światowy Dzień Zdrowia Psychicznego i Międzynarodowy Dzień Osób Niepełnosprawnych ${ }^{23}$.

21 社會福利, 香港年報, (se5 wui2 fuk1 lei6, hoeng1 gong2 nin4 bou3) 2018, op. cit., s. 164165.

22 社會福利, 香港年報, (se5 wui2 fuk1 lei6, hoeng1 gong2 nin4 bou3) 2017, op. cit., s. 166; 社 會福利, 香港年報, (se5 wui2 fuk1 lei6, hoeng1 gong2 nin4 bou3) 2018, op. cit., s. 165.

23 社會福利, 香港年報, (se5 wui2 fuk1 lei6, hoeng1 gong2 nin4 bou3) 2017, op. cit., s. 166167; 社會福利, 香港年報, 2018, op. cit., s. 165. 


\subsection{Komitet Sterujący do spraw Promocji Wolontariatu}

Do zakresu zadań statutowych Komitetu Sterującego do spraw Promocji Wolontariatu (推廣義工服務督導委員會) należy jego propagowanie oraz wspieranie w Hongkongu. Odpowiedzialny jest za opracowywanie ogólnych strategii promocji woluntariatu, a także za koordynację w tym obszarze aktywności departamentów rządowych oraz różnych sektorów gospodarki celem zwiększenia integracji społecznej.

W Departamencie Opieki Społecznej (DOS) we wrześniu 1997 roku utworzono centralne Biuro do spraw Wolontariatu, którego zadaniem było rozwijanie w bardziej skoordynowany sposób wolontariatu poprzez uruchomienie Ruchu Wolontariatu. W celu ułatwienia opracowania listy wolontariuszy utworzono komputerową bazę danych do gromadzenia informacji o wolontariuszach indywidualnych i korporacyjnych.

Ruch Wolontariuszy został formalnie uruchomiony w 1998 roku. Zgodnie z implementacją Ruchu Wolontariatu w każdym z jedenastu okręgów Wydział Opieki Społecznej utworzył okręgowy komitet koordynacyjny do spraw promocji wolontariatu, aby pomóc we wdrażaniu strategii Ruchu. Komitet między innymi uwzględnia warunki istniejące w każdej dzielnicy podczas formułowania strategii promowania wolontariatu, a także koordynuje zasoby dystryktu, aby wywierać większy wpływ na społeczność lokalną. Powołał także specjalne biura do spraw wolontariatu w każdej z jedenastu dzielnic Hongkongu. Zapewnią one pomoc i wsparcie agencjom lub organizacjom zainteresowanym utworzeniem zespołów wolontariuszy i nowo utworzonym zespołom w rejonie ${ }^{24}$.

Celem Ruchu Wolontariuszy jest między innymi: budowanie solidarnej społeczności (budowanie społeczeństwa obustronnego zainteresowania), promowanie pozytywnych wartości samorealizacji, dobre wykorzystywanie zasobów społeczności, wzmocnienie poczucia dobrobytu społecznego (przynależności jednostki do społeczeństwa $)^{25}$.

We wrześniu 1999 roku utworzono Komitet Sterujący do spraw Ruchu Wolontariuszy, który w 2003 roku przemianowano na Komitet Sterujący do spraw Promocji Wolontariatu. Został on odpowiedzialny za opracowywanie ogólnych strategii promocyjnych i planów dotyczących Ruchu Wolontariuszy w Hongkongu. Członkami tej Komisji są przedstawiciele różnych sektorów społeczności i różnych ministerstw. Główne cele promocji Ruchu Wolontariuszy sprowadzają się do:

- ukazania koncepcji wolontariatu jako interesującej i wieloaspektowej działalności promującej w ten sposób wolontariat jako element codziennego życia każdego obywatela;

24 關於我們, 義工運動, (gwaan1 jyu1 ngo5 mun4, ji6 gung1 wan6 dung6) Volunter Movement, https://www.volunteering-hk.org/tc/aboutvs/vs about (dostęp: 2.04.2019).

25 目的, 義工運動, (muk6 dik1, ji6 gung1 wan6 dung6) Volunter Movement, https://www. volunteering-hk.org/tc/aboutvs/vs_objective (dostęp: 2.04.2019). 
— zintensyfikowania (wzmocnienia) działań reklamowych, aby więcej osób mogło rozpoznać wkład wolontariuszy w społeczność;

— uzyskania większego wsparcia i udziału z różnych sektorów (branż).

Głównymi grupami docelowymi pozyskania woluntariuszy są studenci, młodzież, korporacje i wszelkiego rodzaju organizacje społeczne ${ }^{26}$.

Komitet Sterujący promuje trwały wolontariat i zachęca wolontariuszy do włączenia podstawowych wartości i idei wolontariatu do ich codziennego życia. Do końca roku 2016 ponad 2930 organizacji i ponad 1,27 miliona osób zarejestrowało się w wolontariacie na stronie internetowej wolontariatu DOS. W roku następnym ich liczba wzrosła do ponad 3100 organizacji i ponad 1,29 miliona osób 27 .

Z przeprowadzonych badań działalności wolontariatu w Hongkongu wynika, że przedsiębiorstwa, które angażują swoich pracowników w usługi wolontariackie, mają lepszy profil firmy i wizerunek, a także silniejsze relacje ze społecznością. Ich pracownicy mają wyższe morale pracy oraz ducha zespołowego i poczucie jedności, co w sumie daje kluczowe czynniki sukcesu w biznesie. Przykładem udanych korporacyjnych programów wolontariatu w Hongkongu są między innymi takie przedsięwzięcia realizowane przez firmy:

- przygotowywanie goracej zupy lub jedzenia w okresach świątecznych oraz rozprowadzanie ich wśród potrzebujących;

— edukacja w zakresie wiedzy komputerowej dzieci z rodzin znajdujących się w niekorzystnej sytuacji materialnej;

— darmowa obsługa infolinii organizacji opieki społecznej;

- oferowanie bezpłatnych porad prawnych dla osób starszych oraz pomaganie im w zarządzaniu nieruchomościami;

- organizowanie treningów sportowych dla grupy młodych ludzi przez zakładowe kluby sportowe.

Zakres usług wolontariatu w Hongkongu obejmuje ciekawe i zróżnicowane działania, wśród nich można podać następujące przykłady różnych typów wolontariatu:

— prace administracyjne, biurowe, badawcze i projektowe, zarządzanie (takie jak pisanie, sortowanie listów, zarządzanie książkami, obsługa komputera, tłumaczenia itp.);

— usługi towarzyskie (na przykład dla osób niepełnosprawnych, w podeszłym wieku i dzieci) oraz konwojowanie lub eskortowanie (na przykład osób starszych, które są chore albo niepełnosprawnych o ograniczonej mobilności, a także dzieci pozbawionych opieki);

26 義工服務組織圖, 推廣義工服務督導委員會, (ji6 gung1 fuk6 mou6 zou2 zik1 tou4, teoi1 gwong2 ji6 gung1 fuk6 mou6 duk1 dou6 wai2 jyun4 wui2), https://www.volunteering-hk.org/tc/ aboutvs/vs_orgchart (dostęp: 2.04.2019).

27 社會福利, 香港年報, (se5 wui2 fuk1 lei6, hoeng1 gong2 nin4 bou3) 2017, op. cit., s. 167; 社 會福利, 香港年報, (se5 wui2 fuk1 lei6, hoeng1 gong2 nin4 bou3) 2018, op. cit., s. 165. 
— odwiedziny (wizyty) (na przykład odwiedzanie osób samotnych w podeszłym wieku, pacjentów, seniorów, dzieci, osób niepełnosprawnych itp.);

- praca ręczna (na przykład sprzątanie i inne prace w gospodarstwie domowym, prace renowacyjne);

- zaprzyjaźnienie się (na przykład „służenie jako starsi bracia i starsze siostry", aby pomagać dzieciom i młodzieży, lub jako rówieśnicy do opieki nad potrzebującymi);

— planowanie i organizowanie programów masowych (wydarzeń na dużą skalę, takich jak wieczory integracyjne, kluby rozrywkowe lub plany usług wolontariatu);

— zapewnienie profesjonalnej obsługi i pomocy (jak usługi medyczne, programowanie komputerowe, produkcja audio i wideo itp.);

- ochrona środowiska i prace konserwatorskie (na przykład ekologizacja lub rozpowszechnianie informacji o środowisku itp.);

- pomoc w pozyskiwaniu funduszy ${ }^{28}$.

W 2018 roku podczas spotkania w sprawie wolontariatu pracowniczego oraz „ceremonii wręczenia wyróżnień za pracę” dla firm udzielających się w wolontariacie sponsorowanego przez Komitet Sterujący do spraw Promocji Wolontariatu przyznano nagrody w kategoriach:

- na najlepszy program wolontariatu korporacyjnego w okresie 2016-2018,

— wolontariatu obejmującego 10000 godzin w 2017 roku, nych ${ }^{29}$.

- certyfikaty ukończenia trzynastego szkolenia dla wolontariuszy korporacyj-

Lista firm otrzymujących nagrody w wymienionych kategoriach zamieszczona na stronie volunteering-hk.org jest imponująca.

\section{Pomoc finansowa z opieki społecznej}

Priorytetowym celem zabezpieczenia społecznego w Hongkongu jest wsparcie członków społeczności potrzebujących pomocy ekonomicznej (finansowej) lub materialnej, by mogli zaspokoić swoje podstawowe i socjalne potrzeby. Pomoc finansowa z opieki społecznej obejmuje osoby samotnie wychowujące dzieci, rodziny wielodzietne o niskich dochodach wychowujące małe dzieci lub osoby tymczasowo bezrobotne oraz wszystkie te, które potrzebują krótkoterminowej pomocy finansowej.

28 企業義工隊, (kei5 jip6 ji6 gung1 deoi6), https://www.volunteering-hk.org/tc/aboutvs/jv_ corp_team (dostęp: 2.04.2019).

292018 企業義務工作分享會暨嘉許禮, (kei5 jip6 ji6 mou6 gung1 zok3 fan1 hoeng2 wui2 kei3 gaa1 heoi2 lai5), https://www.volunteering-hk.org/tc/2018CVCeremony (dostęp: 6.04.2019). 
Departament Opieki Społecznej wdrożył do praktyki życia społecznego Hongkongu specyficzny „nieskładkowy” system zabezpieczenia społecznego, który nie obejmuje składek odprowadzanych od wynagrodzeń na ubezpieczenia społeczne w celu osiągnięcia powyższych celów. System obejmuje kompleksowy program pomocy socjalnej, program zasiłków z ubezpieczenia społecznego, program odszkodowań z tytułu przemocy i egzekwowania prawa, program pomocy dla ofiar wypadków drogowych oraz pomoc w nagłych wypadkach ${ }^{30}$.

\subsection{Zasiłek dla rodzin pracujących o niskich dochodach}

Program zasiłku dla rodzin pracujących o niskich dochodach (低收入在職家 庭津貼), obsługiwany przez Biuro do spraw Dodatków dla Pracujących Rodzin, ma na celu zmniejszenie obciążeń finansowych rodzin pracujących z gospodarstw domowych o niskich dochodach, zwłaszcza tych mających dzieci, aby zachęcić je do samodzielności i zmniejszyć ubóstwo międzypokoleniowe.

Zgodnie z założeniami programu gospodarstwo domowe składające się z dwóch lub większej liczby członków, spełniające wymóg dotyczący godzin pracy oraz określone limity dochodów i majątku może ubiegać się o dodatek podstawowy lub wyższy zasiłek. Dodatkowo może także otrzymać zasiłek na każde uprawnione dziecko.

Program ten działa od maja 2016 roku. Biuro ze złożonych 52100 wniosków zatwierdziło $33100 \mathrm{z}$ nich do końca roku, przyznając uprawnienia w wysokości 391 mln HKD dla około 28800 rodzin i 104100 osób, w tym około 46300 dzieci i młodzieży. W 2017 roku zatwierdzono ponad 45800 wniosków z około 56800 złożonych, przyznając uprawnienia w wysokości około 529 mln HKD dla 31400 gospodarstw domowych i 114800 osób, w tym 50800 dzieci i młodzieży.

Rząd dokonał kompleksowej oceny realizacji programu w 2017 roku. W jej rezultacie od 1 kwietnia 2018 roku rozpoczął wdrażanie licznych ulepszeń, które obejmują rozszerzenie programu na jednoosobowe gospodarstwa domowe, złagodzenie limitów dochodu i wymogów dotyczących godzin pracy oraz zwiększenie kwoty świadczenia. Nazwa programu została zmieniona na Zasiłek dla rodzin pracujących $(\mathrm{ZRP})^{31}$.

W ramach programu ZRP gospodarstwa domowe (w tym gospodarstwa domowe singli) spełniające wymogi dotyczące godzin pracy, dochodu i limitu aktywów (majątku) mogą ubiegać się o zasiłek podstawowy, zasiłek średni lub wyższy zasiłek. W zależności od dochodu gospodarstwa domowego dodatki mogą być przyznawane według pełnej stawki, trzech czwartych lub połowy stawki. Dodatek jest obliczany miesięcznie, to znaczy gospodarstwo domowe otrzymuje dodatek za

30 社會保障>簡介及目標, (se5 wui2 bou2 zoeng3 > gaan2 gaai3 kap6 muk6 biu1), https://www. swd.gov.hk/tc/index/site_pubsvc/page_socsecu/sub_introducti/(dostęp: 6.04.2019).

31 社會福利, 香港年報, (se5 wui2 fuk1 lei6, hoeng1 gong2 nin4 bou3) 2017, op. cit., s. 162-163; 社會福利, 香港年報, (se5 wui2 fuk1 lei6, hoeng1 gong2 nin4 bou3) 2018, op. cit., s. 161 
każdy miesiąc, w którym spełnione są kryteria kwalifikowalności. Godziny pracy wszystkich członków gospodarstwa domowego mogą być sumowane, a wnioskodawca i jego członkowie mogą zgłaszać godziny pracy z więcej niż jednej pracy wykonywanej w tym samym miesiącu.

Tabela 2. Wymagania dotyczące godzin pracy i kwoty uprawnień

\begin{tabular}{|c|c|c|}
\hline $\begin{array}{l}\text { Całkowity miesięczny czas } \\
\text { pracy (godziny) }\end{array}$ & $\begin{array}{l}\text { Miesięczny dodatek na każde } \\
\text { gospodarstwo domowe }\end{array}$ & $\begin{array}{c}\text { Miesięczny zasiłek na } \\
\text { dziecko dla każdego dziecka }\end{array}$ \\
\hline $\begin{array}{c}144 \text { do mniej niż } 168 \\
\text { (gospodarstwa domowe } \\
\text { niebędące samotnymi } \\
\text { rodzicami) } \\
36 \text { do mniej niż } 54 \text { (gospo- } \\
\text { darstwa domowe samotnie } \\
\text { wychowujące dzieci) }\end{array}$ & $\begin{array}{l}\text { pełny zasiłek podstawowy: } \\
\qquad 800 \mathrm{HKD} \\
\text { trzy czwarte zasiłku podsta- } \\
\text { wowego: } 600 \mathrm{HKD} ; \\
\text { połowa podstawowego } \\
\text { zasiłku: } 400 \mathrm{HKD}\end{array}$ & \multirow{3}{*}{$\begin{array}{c}\text { pełny zasiłek na dziecko: } \\
1000 \mathrm{HKD} \\
\text { trzy czwarte zasiłku na } \\
\text { dziecko: } 750 \mathrm{HKD} \\
\text { połowa zasiłku na dziecko: } \\
500 \mathrm{HKD}\end{array}$} \\
\hline $\begin{array}{c}168 \text { do mniej niż } 192 \\
\text { (gospodarstwa domowe } \\
\text { niebędące samotnymi } \\
\text { rodzicami) } \\
54 \text { do mniej niż } 72 \text { (gospo- } \\
\text { darstwa domowe samotnie } \\
\text { wychowujące dzieci) }\end{array}$ & $\begin{array}{c}\text { pełna kwota średniego } \\
\text { dodatku: } 1000 \mathrm{HKD} \\
\text { trzy czwarte kwoty średniego } \\
\text { dodatku: } 750 \mathrm{HKD} ; \\
\text { połowa średniego dodatku: } \\
500 \mathrm{HKD}\end{array}$ & \\
\hline $\begin{array}{c}192 \text { lub więcej (gospodarstwa } \\
\text { domowe niebędące samotny- } \\
\text { mi rodzicami) } \\
72 \text { lub więcej (gospodarstwa } \\
\text { domowe samotnie wychowu- } \\
\text { jące dzieci) }\end{array}$ & $\begin{array}{l}\text { pełny wysoki zasiłek: } 1200 \\
\text { HKD; } \\
\text { trzy czwarte kwota wysokie- } \\
\text { go zasiłku: } 900 \text { HKD; } \\
\text { połowa wysokości zasiłku: } \\
600 \text { HKD }\end{array}$ & \\
\hline
\end{tabular}

Źródło: 津貼金額,在職家庭津貼計劃 (職津計劃), (zeon1 tip3 gam1 ngaak6,zoi6 zik1 gaa1 ting4 zeon1 tip3 gai3 waak6 (zik1 zeon1 gai3 waak6)), https://www.wfsfaa.gov.hk/wfao/tc/amount.htm (dostęp: 1.04.2019).

Należy podkreślić, że otrzymanie pomocy socjalnej zależy od przepracowania minimalnych godzin pracy. Ze wzrostem ich liczby rośnie wielkość (suma) otrzymywanego świadczenia. Warunek ten ma na celu zwiększenie aktywności zawodowej osób otrzymujących świadczenie socjalne, na przykład:

- rodziny z gospodarstw domowych wychowujące dzieci, niebędące samotnymi rodzicami o łącznym miesięcznym czasie pracy krótszym niż 144 godziny, mogą ubiegać się o zasiłek podstawowy. Natomiast jeśli łączny miesięczny czas pracy nie jest krótszy niż 168 godzin, mogą ubiegać się o średni zasiłek, a jeśli łączny miesięczny czas pracy wynosi 192 godziny lub więcej, mogą wystąpić o wyższe zasiłki;

- osoby z jednoosobowych gospodarstw domowych o łącznym miesięcznym czasie pracy nie krótszym niż 36 godzin mogą ubiegać się o zasiłek podstawowy. 
Natomiast jeśli łączny miesięczny czas pracy nie jest krótszy niż 54 godziny, mogą ubiegać się o średni zasiłek, a gdy łączny miesięczny czas pracy wynosi 72 godziny lub więcej — o wyższe zasiłki;

— rodzice samotnie wychowujący dzieci muszą pracować i mieszkać z co najmniej jednym dzieckiem w wieku poniżej 15 lat. Takie same uprawnienia ma każde kwalifikujące się dziecko mieszkające w jednoosobowym gospodarstwie domowym, którego osoba prowadząca nie jest rodzicem samotnie wychowującym dziecko; może również otrzymywać zasiłek w ramach programu Zasiłek dla osób pracujących. Warunkiem otrzymania zasiłku na dziecko w ramach tego programu jest posiadanie przez prowadzącego gospodarstwo domowe uprawnionego dziecka lub dzieci w wieku poniżej 15 lat lub w wieku między 15 a 21 lat, które uczą się lub kształcą w pełnym wymiarze czasu (nie dotyczy edukacji pomaturalnej lub na poziomie policealnym) $)^{32}$.

Miesięczne górne limity dochodu gospodarstwa domowego w wypadku uprawnień:

- pełnopłatnych ustalono na 50\% średniego miesięcznego dochodu krajowego aktywnych ekonomicznie gospodarstw domowych;

- trzech czwartych stawki ustalane są na poziomie przekraczającym 50\%, ale nie wyższym niż 60\% średniego miesięcznego krajowego dochodu domowego aktywnych ekonomicznie gospodarstw domowych;

— połowy stawki są ustalone na poziomie przekraczającym $60 \%$, ale nie wyższym niż 70\% średniego miesięcznego dochodu krajowego dla gospodarstw domowych aktywnych zawodowo.

Całkowity miesięczny dochód gospodarstwa domowego obejmuje:

1. płace (po odliczeniu obowiązkowej składki pracowników na obowiązkowy program funduszu Provident);

2. opłaty otrzymane za świadczone usługi, zyski z działalności gospodarczej, dochód z wynajmu itp., a także pomoc udzieloną przez rząd, czyli:

- dodatki otrzymane przez członków gospodarstwa domowego z indywidualnej subwencji na transport motywacyjny;

- świadczenia otrzymane w ramach programu pilotażowego dotyczącego zasiłku na utrzymanie dla opiekunów osób starszych z rodzin o niskich dochodach;

— świadczenia otrzymane w ramach programu pilotażowego dotyczącego zasiłku na utrzymanie dla opiekunów osób niepełnosprawnych o niskich dochodach.

Godziny pracy obejmują: godziny płatnej pracy wykonywanej przez wnioskodawcę i innych pracujących członków gospodarstwa domowego, te godziny pra-

32 計劃特色, 在職家庭津貼計劃(職津計劃); (gai3 waak6 dak6 sik1, zoi6 zik1 gaa1 ting4 zeon1 tip3 gai3 waak6 (zik1 zeon1 gai3 waak6)), https://www.wfsfaa.gov.hk/wfao/tc/key_features. htm (dostęp: 1.04.2019). 
cy są sumowane dla aplikacji ZRP (zatrudniony lub samozatrudniony); godziny wynikające z płatnych wakacji i nieobecności, takich jak urlop chorobowy i urlop macierzyński.

Reasumując, przysługujące dodatki finansowe, o które mogą się ubiegać pracujący: rodziny (pełne, niepełne), samotni rodzice oraz osoby wychowujące uprawnione do zasiłku dzieci w wieku poniżej 15 lat (wspólnie z nimi zamieszkujące), uwarunkowane są wymogiem spełnienia określonego miesięcznego czasu pracy ${ }^{33}$ przedstawionego $\mathrm{w}$ tabeli 2.

Warunkiem otrzymania dodatków finansowych jest wymóg, że każdy członek kwalifikującego się gospodarstwa domowego musi mieszkać w Hongkongu, a gospodarstwo domowe ogólnie odnosi się do jednostki, w której osoby mają bliskie więzi gospodarcze i mieszkają w tych samych pomieszczeniach ${ }^{34}$.

Przyjęta gradacja miesięcznego czasu pracy zasiłków pomocowych wskazuje, że realizowana polityka społeczna ma na celu zaktywizowanie zawodowe ludności, premiując te osoby, które starają się osiągnąć w miesiącu jak największą liczbę godzin pracy, co potwierdza przyjętą tezę, że polityka społeczna Hongkongu nie opiera się na zasadzie „rozdawnictwa”.

Potwierdzeniem tej tezy jest również przepis, że w tym samym miesiącu nie mogą być jednocześnie odbierane wraz z Zasiłkiem dla osób pracujących następujące programy:

1. Kompleksowa pomoc socjalna;

2. Indywidualna subwencja na transport motywacyjny (dojazd do pracy). Dotyczy to wnioskodawcy Zasiłku dla rodzin pracujących i innych członków gospodarstwa domowego, których godziny pracy zostały zebrane w celu ubiegania się o ZRP. Natomiast członkowie gospodarstwa domowego, których godziny pracy nie zostały połączone w celu ubiegania się o ZRP, mogą ubiegać się o Indywidualny zasiłek na dojazd do pracy.

Począwszy od 1 kwietnia 2019 roku, zasiłek dla osób pracujących nie zalicza się do dochodów z wynajmu mieszkań publicznych (tym samym nie jest traktowany jako dochód dla wnioskodawców z sektora wynajmu publicznego). Jest też pośrednim środkiem łagodzącym trudną sytuację mieszkaniową w kraju, w którym brakuje wolnych działek budowlanych, a pod budowę domów socjalnych odzyskuje się grunty morskie (antropogeniczne).

Przytoczone przepisy uniemożliwiają powiększanie dochodów gospodarstw domowych przez korzystanie z różnych źródeł opieki społecznej. Zapewniają tym samym kierowanie jej do osób wyłącznie na nią zasługujących.

33 申請資格, 在職家庭津貼計劃 (職津計劃), (san1 cing2 zi1 gaak3, zoi6 zik1 gaal ting4 zeon1 tip3 gai3 waak6 (zik1 zeon1 gai3 waak6)), https://www.wfsfaa.gov.hk/wfao/tc/eligibility.htm (dostęp: 1.04.2019).

34 Ibidem. 
Analizując wysokość dochodów mieszkańców Hongkongu, poza dochodami $\mathrm{z}$ pracy oraz pochodzącymi z aktywów ${ }^{35}$ należy uwzględnić $\mathrm{w}$ dochodzie gospodarstwa domowego pomoc finansową z sektora opieki społecznej:

— indywidualne subwencje na transport motywacyjny (dojazd do pracy),

— świadczenia otrzymane w ramach programu pilotażowego dotyczącego zasiłku na utrzymanie dla opiekunów osób starszych z rodzin o niskich dochodach,

- świadczenia otrzymane w ramach programu pilotażowego dotyczącego zasiłku na utrzymanie dla opiekunów osób niepełnosprawnych o niskich docho$\operatorname{dach}^{36}$.

\subsection{Zabezpieczenie społeczne}

Kompleksowy program pomocy społecznej (KPPS) oraz System zasiłków socjalnych (SZS) z tytułu zabezpieczenia społecznego są podstawą systemu zabezpieczenia społecznego w Hongkongu, uzupełnionego trzema systemami odszkodowań za wypadki:

— programem odszkodowań z tytułu przemocy i egzekwowania prawa,

- programem pomocy ofiarom wypadków drogowych,

- awaryjnym funduszem pomocy w nagłych wypadkach.

Systemy te są zarządzane przez 41 zespołów do spraw ubezpieczenia społecznego i dwa centralne biura ${ }^{37}$.

Kompleksowy program pomocy społecznej (綜合社會保障援助計 劃) zapewnia system bezpieczeństwa osobom i rodzinom, które nie mogą się utrzymać finansowo. Jego celem jest doprowadzenie ich dochodów do określonego poziomu, tak aby zaspokoić ich podstawowe potrzeby ${ }^{38}$.

Ubiegający się o pomoc z nieskładkowego programu KPPS są sprawdzani pod względem finansowym, ponadto muszą spełnić warunek miejsca zamieszkania. Osoby w trudnej sytuacji finansowej otrzymują pomoc pieniężną na zaspokojenie podstawowych potrzeb. Na koniec 2017 roku złożono 231134 wnioski o udzielenie pomocy, w 2016 roku — 237056 , jej beneficjentami w tych latach było 336681 oraz 348831 osób. Łączne wydatki programu w 2016 roku wyniosły 21,4 mld HKD i były o 4,3\% mniejsze w stosunku do poprzedniego roku. Całkowite

35 Aktywa gospodarstwa domowego obejmują: ziemię, nieruchomości ziemskie (z wyjątkiem nieruchomości zajmowanych przez siebie), pojazdy, statki, taksówki, małe publiczne licencje autobusowe, inwestycje, akcje, przedsięwzięcia biznesowe oraz depozyty bankowe, gotówkę itp.

36 與政府其他援助計劃的關係, 在職家庭津貼計劃 (職津計劃), (jyu5 zing3 fu2 kei4 taa1 wun4 zo6 gai3 waak6 dik1 gwaan1 hai6, zoi6 zik1 gaal ting4 zeon1 tip3 gai3 waak6 (zik1 zeon1 gai3 waak6)), https://www.wfsfaa.gov.hk/wfao/tc/interface.htm (dostęp: 1.04.2019).

37 社會福利, 香港年報, (se5 wui2 fuk1 lei6, hoeng1 gong2 nin4 bou3) 2018, s. 161.

38 綜合社會保障援助(綜援)計劃, (zung1 hap6 se5 wui2 bou2 zoeng3 wun4 zo6 (zung1 wun4) gai3 waak6), https://www.swd.gov.hk/tc/index/site_pubsvc/page_socsecu/sub_comprehens/(dostęp: 6.04.2019). 
wydatki w 2017 roku wyniosły około 21,7 mld HKD, co oznacza wzrost o 1\% w stosunku do poprzedniego roku ${ }^{39}$.

Przenośny program kompleksowej pomocy społecznej pozwala osobom starszym, które spełniają określone kryteria, czyli otrzymywały KPPS nieprzerwanie przez co najmniej jeden rok, na kontynuowanie pomocy w prowincji Guangdong lub Fujian (ChRL), jeśli zdecydują się one na stałe przejść tam na emeryturę ${ }^{40}$.

Wsparcie dla systemu samodzielności (自力更生支援計劃 — WSS). Celem programu WSS jest pomoc w zwiększeniu szans na zatrudnienie i możliwości zatrudnienia.

Departament Pomocy Społecznej w ramach Zintegrowanego programu pomocy w zakresie zatrudnienia dla samodzielności (自力更生綜合就業援助計劃) zlecił organizacjom pozarządowym jego obsługiwanie. Mają one pomagać pełnosprawnym bezrobotnym, zdolnym do pracy odbiorcom KPPS w wieku od 15 do 59 lat oraz samotnym rodzicom i opiekunom dzieci, których najmłodsze dziecko jest w wieku od 12 do 14 lat, w pokonaniu barier w znalezieniu pracy oraz poprawić ich zdolność do zatrudnienia, aby mogli otrzymać płatne zatrudnienie tak szybko jak to możliwe i stali się samodzielni dzięki wprowadzeniu wielu przepisów obejmujących kompleksowe usługi pomocy w zakresie zatrudnienia na zasadach rodzinnych.

W programie Wsparcie dla systemu samodzielności nie muszą uczestniczyć bezrobotni wnioskodawcy KPPS w wieku od 15 do 59 lat, jeśli znaleźli zatrudnienie w wymiarze nie mniejszym niż 120 godzin miesięcznie, a zarobki ich nie są niższe niż poziom określony przez Departament Pomocy Społecznej, lub bezrobotni wnioskodawcy KPPS w wieku od 60 do 64 lat, którzy znaleźli zatrudnienie w wymiarze nie mniejszym niż 60 godzin miesięcznie lub samotni rodzice i opiekunowie dzieci z najmłodszym dzieckiem w wieku od 12 do 14 lat, którzy znaleźli zatrudnienie w wymiarze nie mniejszym niż 32 godziny w miesiącu.

Aby zachęcić wnioskodawców Kompleksowego Programu Pomocy Socjalnej do poszukiwania i kontynuowania pracy wprowadzono przepis „Zintegrowane zarobki” (豁免計算入息) dotyczący zwolnienia z obliczania dochodu w ramach tego programu ${ }^{41}$.

39 社會福利, 香港年報, (se5 wui2 fuk1 lei6, hoeng1 gong2 nin4 bou3) 2017, op. cit., s. 163; 社 會福利，香港年報, (se5 wui2 fuk1 lei6, hoeng1 gong2 nin4 bou3) 2018, op. cit., s. 161.

40 綜援長者廣東及福建省養老計劃, (zung1 wun4 coeng4 ze2 gwong2 dung1 kap6 fuk1 gin3 saang2 joeng5 lou5 gai3 waak6), https:/www.swd.gov.hk/tc/index/site_pubsvc/page_socsecu/ sub portableco/ (dostęp: 6.04.2019).

$\overline{41}$ 自力更生支援計劃, (zi6 lik6 gang3 saang1 zi1 wun4 gai3 waak6), https://www.swd.gov.hk/ tc/index/site_pubsvc/page_socsecu/sub_supportfor/(dostęp: 6.04.2019). 
Na koniec roku 2016 w programie wzięło udział 76743 odbiorców KPPS, do końca 2017 roku zaś $87731^{42}$.

Zintegrowany program pomocy w znalezieniu zatrudnienia dla samodzielności (ZPPZZS) adresowany jest do różnych grup wiekowych mieszkańców Hongkongu znajdujących się w różnych sytuacjach życiowych. „Samodzielność” oznacza, że mogą oni zmienić swoje życie, mogą zmienić (poprawić) samodzielnie swoją sytuację życiową dzięki własnej zaradności (bez polegania wyłącznie na rządzie). Program KPPS obejmuje osoby bezrobotne, które są:

1. w wieku 15-59 lat, sprawne fizycznie i zdrowe (w Hongkongu dzieciom poniżej 15 roku życia zabrania pracy we wszystkich przedsiębiorstwach przemysłowych rozporządzenie o zatrudnieniu. Dozwolone jest powyżej 15 lat);

2. są samotnymi rodzicami (lub rozwiedzionymi), a ich najmłodsze dziecko ma 12-14 lat. Uważa się, że dziecko, które ma 12 lat, już dorosło i jest zdolne do samoopieki i nie ma potrzeby się nim opiekować. Natomiast jeśli ma mniej niż 12 lat, osoba nie musi dołączać do Zintegrowanego programu pomocy w zakresie zatrudnienia dla samodzielności, ponieważ musi dbać o dziecko i nie ma wolnego czasu na pracę.

Udział w programie gwarantuje, że objęte nim osoby otrzymują co miesiąc pomoc od rządu.

Fundusz Opieki Społecznej wdrażał do marca 2017 roku pilotażowy program motywacyjny, który miał na celu zachęcić beneficjentów Kompleksowego programu opieki społecznej do wzięcia udziału w Samowystarczalnym kompleksowym programie pomocy w zakresie zatrudnienia dla samodzielności (“進一步鼓勵“自 力更生綜合就業援助計劃”綜援受助人就業的獎勵計劃”) 43 .

W 2016 roku Fundusz Opieki Społecznej kontynuował pilotażowy „Program motywacyjny 'samowystarczalny (samodzielny) kompleksowy program pomocy w zakresie zatrudnienia' w celu dalszego zachęcania odbiorców KPPS do zatrudniania poprzez system nagród za zatrudnienie” (“進一步鼓勵“自力更生綜合 就業援助計劃'綜援受助人就業的獎勵計劃”). Ten program został ukończony W marcu 2017 roku.

Analizując zasady działania Kompleksowego programu pomocy społecznej, należy podkreślić, że nastawiony jest on na poprawę dobrobytu mieszkańców Hongkongu poprzez ich aktywizację zawodową pomagającą w znalezieniu pracy lub jej kontynuowaniu, a tylko w uzasadnionych wypadkach udzielenia pomocy niepracującym. Realizowana polityka społeczna wyklucza tworzenie świadczeń socjalnych według wzoru zachodnich państw opiekuńczych. Tym samym unika tworzenia „kultury zależności”, w której poziom życia ubogich obywateli zależy wyłącznie od dobrej woli państwa.

42 社會福利, 香港年報, (se5 wui2 fuk1 lei6, hoeng1 gong2 nin4 bou3) 2017, op. cit., s. 163; 社 會福利, 香港年報, (se5 wui2 fuk1 lei6, hoeng1 gong2 nin4 bou3) 2018, op. cit., s. 161.

43 社會福利, 香港年報, (se5 wui2 fuk1 lei6, hoeng1 gong2 nin4 bou3) 2017, op. cit., s. 163. 


\subsection{Zasiłek socjalny}

Celem Programu zasiłków z tytułu zabezpieczenia społecznego (PZZS) jest zapewnienie miesięcznego dodatku dla mieszkańców Hongkongu o znacznym stopniu niepełnosprawności w wieku 65 lat lub więcej, który ma pomóc zaspokoić ich specjalne potrzeby wynikające z niepełnosprawności lub podeszłego wieku. Program obejmuje wiele zasiłków, jak: ogólny zasiłek inwalidzki (普通傷殘津貼), zasiłek dla osób niepełnosprawnych (高額傷殘津貼), zasiłek emerytalny (高齡 津貼), zwykły zasiłek dla osób starszych (w podeszłym wieku) (普通長者生活津 貼), wysoki zasiłek dla osób starszych (高額長者生活津貼), program Guangdong i program Fujian (廣東計劃及福建計劃) ${ }^{44}$.

Zasiłek na utrzymanie dla osób w podeszłym wieku (長者生活津貼) uzupełnia koszty utrzymania osób w wieku 65 lat i starszych, które potrzebują wsparcia finansowego, natomiast zasiłek emerytalny (高齡津貼) i renta inwalidzka (傷殘津 貼) zapewniają świadczenia pieniężne nieuzależnione od dochodów osobom starszym, które ukończyły 70 lat lub więcej, oraz osobom z poważną niepełnosprawnością, odpowiadając ich szczególnym potrzebom. Program Guangdong zapewnia comiesięczny zasiłek dla mieszkańców Hongkongu w wieku 65 lat i starszym, które decydują się na zamieszkanie w Guangdong.

W styczniu 2017 roku rząd ogłosił cztery nowe inicjatywy:

— od 1 maja złagodzenie limitu aktywów do zasiłku na utrzymanie w wieku starczym celem zapewnienia korzyści większej liczbie osób starszych o potrzebach finansowych;

- wprowadzenie wyższej miesięcznej stawki zasiłku na utrzymanie w wieku starczym w 2018 roku dla osób o większych potrzebach ekonomicznych;

- w ciągu jednego roku od dnia 1 lipca ponownie wdroży specjalne rozwiązanie w ramach projektu Guangdong zwolnienia osób starszych, które przeniosły się do prowincji Guangdong, z wymogu stałego pobytu w Hongkongu na co najmniej rok przed złożeniem wniosku;

— uruchomienie projektu Fujian w 2018 roku, aby przyznać miesięczny zasiłek dla osób starszych (dodatek z tytułu starości), które zdecydowały się przenieść do prowincji Fujian i mają 65 lat lub więcej.

W 2017 roku liczba odbiorców Programu zasiłków z tytułu zabezpieczenia społecznego wynosiła 883 tys., w 2016 roku zaś - 825 262, a całkowite wydatki wyniosły około 23,2 mld HKD w ciągu roku, co stanowi wzrost o $8,2 \%$ w stosunku do 2016 roku (w 2016 roku — 22,2 mld HKD w ciągu roku, wzrost o 2,3\% w stosunku do 2015 roku $)^{45}$.

44 公共福利金計劃, (gung1 gung6 fuk1 lei6 gam1 gai3 waak6), https://www.swd.gov.hk/tc/ index/site pubsvc/page socsecu/sub ssallowance/ (dostęp: 6.04.2019).

45 社會福利, 香港年報, (se5 wui2 fuk1 lei6, hoeng1 gong2 nin4 bou3) 2017, op. cit., s. 163; 社 會福利, 香港年報, (se5 wui2 fuk1 lei6, hoeng1 gong2 nin4 bou3) 2018, op. cit., s. 162. 
Urząd Pracy i Opieki Społecznej utworzył w lutym 2013 roku Międzyresortową Grupę Roboczą do spraw Przeglądu Zasiłku dla Niepełnosprawnych, której zadaniem było zbadanie kwestii umożliwienia osobom z „utratą jednej kończyny” ubiegania się o zasiłek inwalidzki i sprawy pokrewne.

Należy podkreślić, że rząd Hongkongu stopniowo wdraża środki poprawy (sytuacji osób niepełnosprawnych) zalecane przez Międzyresortową Grupę Roboczą do spraw Przeglądu Zasiłku dla Osób Niepełnosprawnych koordynowaną przez Biuro Pracy i Opieki Społecznej, których celem jest pomoc mieszkańcom Hongkongu w zaspokajaniu potrzeb wynikających z ich niepełnosprawności.

W czerwcu 2016 roku rząd przekazał odbiorcom KPPS jedną dodatkową miesięczną standardową kwotę oraz jeden dodatkowy miesięczny dodatek dla odbiorców: zasiłku na utrzymanie dla osób w podeszłym wieku; zasiłku emerytalnego; renty inwalidzkiej (傷殘津貼). W czerwcu 2017 roku rząd przekazał jedną dodatkową miesięczną opłatę standardową odbiorcom KPPS oraz jeden dodatkowy miesięczny dodatek dla osób otrzymujących zasiłek socjalny z tytułu zabezpieczenia społecznego, zasiłek dla rodzin o niskich dochodach oraz dotację z programu na transport motywacyjny do pracy ${ }^{46}$.

\subsection{Odszkodowanie powypadkowe}

Program odszkodowań za obrażenia w sprawach karnych i egzekwowania prawa (暴力及執法傷亡賠償計劃) ma na celu przyznanie odszkodowań finansowych i zapewnienie pomocy finansowej osobom poszkodowanym (lub osobom pozostającym na ich utrzymaniu w wypadku ich śmierci), które doznały obrażeń powstałych w wyniku przestępstwa, przemocy lub spowodowanych przez funkcjonariusza organów ścigania używającego broni przy wykonywaniu swoich obowiązków. Program jest nieskładkowy i nie jest uzależniony od dochodów czy od stanu zamożności ${ }^{47}$. W 2016 roku wypłacono 5,75 mln HKD z programu, natomiast w $2017 \mathrm{roku}-4,82 \mathrm{mln} \mathrm{HKD}^{48}$.

Program pomocy ofiarom wypadków (交通意外傷亡援助計劃) ma zapewnić szybką pomoc finansową ofiarom i osobom poszkodowanym w wypadkach drogowych (lub ich rodzinom, bliskim osobom pozostającym na ich utrzymaniu w wypadku ich śmierci), niezależnie od tego, kto jest odpowiedzialny za wypadek.

46 Ibidem.

47 暴力及執法傷亡賠償計劃, (bou6 lik6 kap6 zap1 faat3 soeng1 mong4 pui4 soeng4 gai3 waak6), https://www.swd.gov.hk/tc/index/site_pubsvc/page_socsecu/sub_criminalan/ (dostęp: 6.04.2019).

48 社會福利, 香港年報, (se5 wui2 fuk1 lei6, hoeng1 gong2 nin4 bou3) 2017, op. cit., s. 164; 社 會福利, 香港年報, (se5 wui2 fuk1 lei6, hoeng1 gong2 nin4 bou3) 2018, op. cit., s. 162. 
Program jest bezskładkowy i nie jest uzależniony od sytuacji materialnej beneficjenta. Płatności dokonywane są za obrażenia ciała, utrata lub uszkodzenie mienia nie są objęte gwarancją ${ }^{49}$. W ciągu roku 2016 wypłacono 245,6 mln HKD z programu, a w 2017 roku $-241,6$ mln $\mathrm{HKD}^{50}$.

\subsection{Pomoc doraźna w nagłych wypadkach}

Funduszem Pomocy doraźnej w nagłych wypadkach zarządza Komitet Funduszu Pomocy Awaryjnej, którego celem jest pomoc osobom poszkodowanym przez klęski żywiołowe. Nadzór nad nim sprawuje dyrektor do spraw opieki społecznej.

Celem Funduszu jest zapewnienie szybkiej pomocy pieniężnej ofiarom klęsk żywiołowych lub innych katastrof (nieszczęśliwych wypadków), takich jak pożar, tajfun, powódź, ulewne deszcze, osunięcie się ziemi i zawalenie się domu, a także ewakuacja osób z budynków i pomieszczeń uznanych za niebezpieczne i których wydano nakaz zamknięcia. Pomoc jest przekazywana w postaci posiłków (dostarczania żywności) lub gotówki zamiast posiłków i innych niezbędnych rzeczy (artykułów pomocowych).

Dotacje z Funduszu pomocy doraźnej w nagłych wypadkach są wypłacane kwalifikującym się ofiarom, a w wypadku ich śmierci osobom pozostającym wcześniej na ich utrzymaniu. Dotacje z Funduszu przeznaczone są na pomoc, a nie na rekompensatę.

Departament Opieki Społecznej odpowiada za wypłatę odszkodowań z tytułu obrażeń ciała lub śmierci, podczas gdy Departament Landów, Departament Morski i Rolnictwa oraz Departament Rybołówstwa i Ochrony są odpowiedzialne za inne kategorie dotacji (subsydiów) ${ }^{51}$. W 2016 roku udzielono pomocy 126 ofiarom jedenastu katastrof, a w 2017 roku -207 ofiarom dwudziestu katastrof ${ }^{52}$.

\subsection{Rada Odwoławcza do spraw Ubezpieczeń Społecznych}

Rada Odwoławcza do spraw Ubezpieczeń Społecznych (社會保障上訴委員會) jest niezależnym organem. Jego główną funkcją jest rozpatrywanie skarg osób niezadowolonych z decyzji Wydziału Opieki Społecznej Departamentu Opieki Społecznej w zakresie kwalifikowalności i wypłaty z Kompleksowej Pomocy z Ubezpieczenia Społecznego dotyczącej zasiłku z tytułu zabezpieczenia społecznego (obejmującego zasiłek z tytułu starości i zasiłek dla osób niepełnosprawnych) oraz programu pomocy ofiarom wypadku drogowego.

49 交通意外傷亡援助計劃, (gaau1 tung1 ji3 ngoi6 soeng1 mong4 wun4 zo6 gai3 waak6), https:/www.swd.gov.hk/tc/index/site_pubsvc/page_socsecu/sub_trafficacc/(dostęp: 6.04.2019).

50 社會福利, 香港年報, (se5 wui2 fuk1 lei6, hoeng1 gong2 nin4 bou3) 2017, op. cit., s. 164; 社 會福利, 香港年報, (se5 wui2 fuk1 lei6, hoeng1 gong2 nin4 bou3) 2018, op. cit., s. 162.

51 緊急救濟, https://www.swd.gov.hk/tc/index/site_pubsvc/page_socsecu/sub_emergencyr/ (dostęp: 6.04.2019).

52 社會福利, 香港年報, (se5 wui2 fuk1 lei6, hoeng1 gong2 nin4 bou3) 2017, op. cit., s. 164; 社 會福利, 香港年報, (se5 wui2 fuk1 lei6, hoeng1 gong2 nin4 bou3) 2018, op. cit., s. 162. 
Decyzje Zarządu są ostateczne i nie tworzą precedensu odnośnie do innych spraw. Odwołać się można do dyrektora opieki społecznej w następujących sprawach: odmowa jakiejkolwiek płatności; kwota oferowanej płatności; data, od której oferowana była płatność; kwestia płatności osobie innej niż wnioskodawca ${ }^{53}$. Zarząd orzekał w sprawie 429 odwołań w 2016 roku i 350 w 2017 roku $^{54}$.

\subsection{Zapobieganie oszustwom i nadużyciom}

Zabezpieczeniem zachowania integralności systemu zabezpieczenia społecznego oraz zapewnieniem właściwego wykorzystania funduszy publicznych zajmuje się Wydział Specjalnego Departamentu do spraw Dochodzeń. Zapobiega on oszustwom i nadużyciom w zakresie zabezpieczenia społecznego oraz je zwalcza. Do jego zadań statutowych należy między innymi prowadzenie szczegółowych dochodzeń wobec podejrzanych oraz dokonywanie ocen wysokości wyłudzeń i odzyskiwanie nadpłat. Otrzymuje informacje od obywateli za pośrednictwem infolinii.

W porównaniu do 2016 roku, w którym 170 przestępców otrzymało nakaz tymczasowego uwięzienia, nakaz wykonania prac społecznych, zostało ukaranych grzywną lub udzielono im ostrzeżeń, w 2017 roku ich liczba uległa zmniejszeniu i wyniosła $126^{55}$.

W celu zapobiegania oszustwom i nadużyciom związanym ze świadczeniami socjalnymi oraz prowadzenia dochodzeń w ich sprawie działa pięć specjalnych zespołów dochodzeniowych pod kierownictwem Specjalnej Sekcji Śledczej Oddziału Ubezpieczeń Społecznych. Specjalizują się one w rozwiązywaniu konkretnych problemów w zakresie właściwego wykorzystania funduszy publicznych. Przykładowo:

— zespoły do spraw dochodzeń w sprawie oszustw (1) i (2) (詐騙案調查隊(1) 和(2)) odpowiedzialne są za przeprowadzenie dogłębnego dochodzenia w sprawie podejrzeń o oszustwa i nadużycia finansowe w zakresie zabezpieczenia społecznego;

— Zespół do spraw oceny oszustw (詐騙案評算隊) odpowiedzialny jest za przeprowadzanie oceny, obliczanie i odzyskiwanie wielu płatności w wypadku podejrzeń o oszustwo w zakresie zabezpieczenia społecznego;

— Zespół weryfikacji danych (資料核對隊) przeprowadza kontrole danych w celu wykrycia nadużywania świadczeń zabezpieczenia społecznego. Odpowiedzialny jest za przeprowadzanie weryfikacji danych we współpracy z innymi ministerstwami i organizacjami rządowymi, czyli: Departamentem Imigracji, Skarbem

53 社會保障上訴委員會, (se5 wui2 bou2 zoeng3 soeng5 sou3 wai2 jyun4 wui2), https://www. swd.gov.hk/tc/index/site_pubsvc/page_socsecu/sub_ssappeal/(dostęp: 6.04.2019).

54 社會福利, 香港年報, (se5 wui2 fuk1 lei6, hoeng1 gong2 nin4 bou3) 2017, op. cit., s. 164; 社 會福利, 香港年報, (se5 wui2 fuk1 lei6, hoeng1 gong2 nin4 bou3) 2018, op. cit., s. 162.

55 社會福利, 香港年報, (se5 wui2 fuk1 lei6, hoeng1 gong2 nin4 bou3) 2017, op. cit., s. 164; 社 會福利, 香港年報, (se5 wui2 fuk1 lei6, hoeng1 gong2 nin4 bou3) 2018, op. cit., s. 163. 
Państwa, Usługami Więziennymi, Rejestrem Gruntów, Rejestrem Spółek, Departamentem Transportu, Studencką Agencją Pomocy Finansowej, Urzędem Szpitala, Komisją Przekwalifikowania Pracowników i Departamentem Pracy;

— Zespół dochodzeniowy (重點調查隊) odpowiedzialny jest za przeprowadzenie pełnego (kompleksowego) przeglądu wraz z kontrolą jakości wybranych losowo spraw w celu zapewnienia integralności danych, poprawności płatności i zgodności z Podręcznikiem procedur zabezpieczenia społecznego, w celu upewnienia się, że informacje są kompletne, zatwierdzona kwota jest dokładna i zgodna z procedurami zabezpieczenia społecznego;

— Zespół informacji i zapytań (查詢) udziela wszechstronnej pomocy w uzyskaniu informacji co do funkcjonowania systemu.

Celem zapobiegania i zwalczania oszustw oraz nadużywania świadczeń z zabezpieczenia społecznego Departament Pomocy Społecznej w ramach wspólnotowego programu edukacyjnego "Zapobieganie fałszerstwom i obrona KPPS” (防止詐騙綜援展示板) zainstalował we wszystkich okręgowych biurach ubezpieczeń społecznych tablice prezentacyjne zapobiegające oszustwom, aby przypomnieć zainteresowanym (odbiorcom Kompleksowego programu pomocy społecznej) o uczciwym zgłoszeniu ich sytuacji oraz aby mieli świadomość powagi popełnienia jakiegokolwiek oszustwa. Dane na temat oszustw w zakresie zabezpieczenia społecznego są regularnie ogłaszane na panelach. W wypadkach niektórych oszustw skutkiem było skazanie osoby wyłudzającej świadczenie społeczne ${ }^{56}$.

\section{Podsumowanie}

Model realizowanej polityki społecznej determinowany jest konstytucyjnymi założeniami przyjętego systemu społeczno-gospodarczego, a także przesłankami politycznymi oraz poziomem zasobów, które określają sposób organizacji usług socjalnych oraz zasady ich finansowania.

Pojęcie dobrobytu jest kategorią względną, zależną od wielu przesłanek, wśród których poza ekonomicznymi ważne znaczenie mają kulturowe, uzupełniające rządowy system pomocy socjalnej poprzez nieformalny system opieki społecznej i wzajemnej pomocy.

Realizowany w Hongkongu kompleksowy program pomocy finansowej z opieki społecznej ma na celu wsparcie jego mieszkańców, których dochody nie wystarczają na zaspokojenie podstawowych potrzeb, poprzez zapewnienie różnego rodzaju płatności. Geneza jego koncepcji odnosi się do 1971 roku, w którym wprowadzono w Hongkongu pierwszy system pomocy publicznej oparty na nieskładkowych ubezpieczeniach społecznych. Kardynalną jego zasadą, zgodną z ideą konfucjanizmu, była odpowiedzialna rola rodziny w opiece społecznej. Zawarto

56 特別調查組, (dak6 bit6 diu6 caa4 zou2), https://www.swd.gov.hk/tc/index/site_pubsvc/ page_socsecu/sub_specialinv/(dostęp: 6.04.2019). 
ją w Białej księdze o opiece społecznej z 1965 roku w formule: „bez względu na to, jak bardzo chcielibyśmy być hojni, nie możemy marnować dolarów i centów, w związku z tym rządowa koncepcja pomocy opiera się na chińskiej tradycji odpowiedzialności rodziny w zakresie samopomocy oraz wsparcia, co jest słuszne $\mathrm{w}$ teorii" ${ }^{\prime 57}$.

Zasada ta wiąże się również z jednym z kanonów polityki gospodarczej Hongkongu, zakładającym między innymi utrzymanie równowagi budżetowej oraz niskiego opodatkowania, co ma sprzyjać zdynamizowaniu wzrostu gospodarczego. Przy tym założeniu polityka społeczna może być wyłącznie niskim procentem wydatków budżetowych. Przykładowo w roku 2017 udział wydatków na politykę socjalną obejmował $1,9 \%$ PKB, gdy w Polsce $16 \%$, co nie oznacza jednak niedofinansowania opieki społecznej w Hongkongu. Finansowana jest ona z innych dochodów pozabudżetowych, co opisane zostanie szerzej w następnym artykule.

Specyfiką polityki społecznej Hongkongu w przeciwieństwie do europejskiego modelu „państwa opiekuńczego” jest realizacja państwa „dobrostanu” mającego na celu dobro całego społeczeństwa. Opieka społeczna jest tym samym co standard życia, ale bardziej dotyczy jakości życia, które obejmuje takie czynniki, jak:

— dostępność ogólnych produktów i usług społecznych,

- religijne i duchowe (kulturowe) aspekty życia,

— jakość środowiska życia i bytu mieszkańców.

W przyjętym modelu polityki społecznej kluczowymi podmiotami świadczenia pomocy społecznej są zarówno państwo, jak i społeczeństwo obywatelskie, w którym ważną rolę odgrywa wsparcie rodziny i członków lokalnej społeczności. W ramach tego modelu wszystkie grupy społeczne w zależności od ich stanu materialnego i produktywności oraz przyjętych kryteriów korzystają z pomocy społecznej.

Na podstawie prezentowanych badań należy stwierdzić, że różnice między europejskim a hongkońskim modelem polityki społecznej wynikają przede wszystkim z uwarunkowań historycznych i kulturowych. Na korzyść tego drugiego przemawia okoliczność, że nie ma w nim powszechnego w Europie „rozdawnictwa”, a środki polityki społecznej przeznaczone są na takie przedsięwzięcia, które służą aktywizacji zawodowej ludności, służącej podnoszeniu poziomu jej życia, na co wskazują kwestie wymienione w tytule rozdziału 6 ustawy zasadniczej Hongkongu, czyli Edukacja, nauka, kultura, sport, religia, praca i opieka społeczna.

Teza ta znajduje potwierdzenie $\mathrm{w}$ opisanych $\mathrm{w}$ artykule sposobach finansowania polityki społecznej (w Hongkongu) prowadzonej przez instytucje odpowiedzialne za jej realizację w zakresie polityki rodzinnej, opieki zdrowotnej, gwarantowanego dochodu podstawowego dla osób starszych, wsparcia dochodów i zatrudnie-

57 Hong Kong Legislative Council. (May 1965). Official Report of Proceedings, s. 303, http:// www.legco.gov.hk/1965/h650512.pdf (dostęp: 5.05.2019). 
nia, pomocy dla osób niepełnosprawnych oraz dla osób ubogich znajdujących się w trudnej sytuacji ekonomicznej.

\section{Bibliografia}

2018 企業義務工作分享會暨嘉許禮, [kei5 jip6 ji6 mou6 gung1 zok3 fan1 hoeng2 wui2 kei3 gaa1 heoi2 lai5; Wspólne spotkanie wolontariatu korporacyjnego i ceremonia wręczenia wyróżnień], https://www.volunteering-hk.org/tc/2018CVCeremony (dostęp: 6.04.2019).

Basic Law, [Prawo podstawowe], https://www.basiclaw.gov.hk/en/basiclawtext/index.html (dostęp: 24.04.2019).

暴力及執法傷亡賠償計劃, [bou6 lik6 kap6 zap1 faat3 soeng1 mong4 pui4 soeng4 gai3 waak6; Program odszkodowań za szkody powstałe w wyniku przemocy i egzekwowania prawa] https:// www.swd.gov.hk/tc/index/site_pubsvc/page_socsecu/sub_criminalan/(dostęp: 6.04.2019).

特別調查組, [dak6 bit6 diu6 caa4 zou2; Specjalny zespół dochodzeniowy], https://www.swd.gov. $\mathrm{hk} / \mathrm{tc} / \mathrm{index} / \mathrm{site}$ pubsvc/page_socsecu/sub_specialinv/(dostęp: 6.04.2019).

簡介, 婦女事務委員會, [gaan2 gaai3, fu5 neoi5 si6 mou6 wai2 jyun4 wui2; Wprowadzenie, Komisja do spraw Kobiet], https://www.women.gov.hk/tc/aboutus/introduction.html (dostęp: 2.04.2019).

簡介, 安老事務委員會, [gaan2 gaai3, ngon1 lou5 si6 mou6 wai2 jyun4 wui2; Wprowadzenie, Komisja do spraw Seniora], https://www.elderlycommission.gov.hk/cn/About_Us/Introduction. html (dostęp: 2.04.2014).

交通意外傷亡援助計劃, [gaau1 tung1 ji3 ngoi6 soeng1 mong4 wun4 zo6 gai3 waak6; Program pomocy ofiarom wypadków drogowych], https://www.swd.gov.hk/tc/index/site_pubsvc/page_ socsecu/sub_trafficacc/(dostęp: 6.04.2019).

計劃特色, 在職家庭津貼計劃(職津計劃); [gai3 waak6 dak6 sik1, zoi6 zik1 gaa1 ting4 zeon1 tip3 gai3 waak6 (zik1 zeon1 gai3 waak6); Funkcje programu, Program dopłat dla rodzin pracujących (plan zatrudnienia)], https://www.wfsfaa.gov.hk/wfao/tc/key_features.htm (dostęp: 1.04.2019).

緊急救濟, [gan2 gap1 gau3 zai3; Pomoc w nagłych wypadkach], https://www.swd.gov.hk/tc/index/ site_pubsvc/page_socsecu/sub_emergencyr/ (dostęp: 6.04.2019).

公共福利金計劃, [gung1 gung6 fuk1 lei6 gam1 gai3 waak6; Program pomocy społecznej], https:// www.swd.gov.hk/tc/index/site_pubsvc/page_socsecu/sub_ssallowance/ (dostęp: 6.04.2019).

關於我們, 義工運動, Volunter Movement, [gwaan1 jyu1 ngo5 mun4, ji6 gung1 wan6 dung6; Informacje o nas, Ruch wolontariuszy] https://www.volunteering-hk.org/tc/aboutvs/vs_about (dostęp: 2.04.2019).

香港特別行政區政府,勞工及福利局,主頁, 歡迎辭, [hoeng1 gong2 dak6 bit6 hang4 zing3 keoi1 zing3 fu2,lou4 gung1 kap6 fuk1 lei6 guk6,zyu2 jip6, fun1 jing4 ci4; Biuro Specjalnego Regionu Administracyjnego Hongkongu, Biuro Pracy i Opieki Społecznej, Strona główna, Mowa powitalna], https://www.lwb.gov.hk/chi/home/index.htm (dostęp: 6.04.2019).

Hong Kong Legislative Council. (May 1965). Official Report of Proceedings, [Rada Legislacyjna Hongkongu (maj 1965 r.) Oficjalne sprawozdanie z postępowań], http:/www.legco.gov. hk/1965/h650512.pdf (dostęp: 5.05.2019).

義工服務組織圖, 推廣義工服務督導委員會, [ji6 gung1 fuk6 mou6 zou2 zik1 tou4, teoi1 gwong2 ji6 gung1 fuk6 mou6 duk1 dou6 wai2 jyun4 wui2; Schemat organizacji wolontariatu, Komitet sterujący ds. promocji wolontariatu,], https://www.volunteering-hk.org/tc/aboutvs/vs_orgchart (dostęp: 2.04.2019).

與政府其他援助計劃的關係, 在職家庭津貼計劃(職津計劃), [jyu5 zing3 fu2 kei4 taa1 wun4 zo6 gai3 waak6 dik1 gwaan1 hai6, zoi6 zik1 gaa1 ting4 zeon1 tip3 gai3 waak6 (zik1 zeon1 gai3 
waak6); Relacje z innymi rządowymi programami pomocy, Program dopłat dla rodzin pracujących (plan zatrudnienia)], https://www.wfsfaa.gov.hk/wfao/tc/interface.htm (dostęp: 1.04.2019). 企業義工隊, [kei5 jip6 ji6 gung1 deoi6; Zespół wolontariuszy korporacyjnych], https://www.volunteering-hk.org/tc/aboutvs/jv_corp_team (dostęp: 2.04.2019).

目的, 義工運動, Volunter Movement, [muk6 dik1, ji6 gung1 wan6 dung6; Cel, Ruch wolontariuszy], https://www.volunteering-hk.org/tc/aboutvs/vs_objective (dostęp: 2.04.2019).

使命及職權範圍, 婦女事務委員會, [sai2 ming6 kap6 zik1 kyun4 faan6 wai4, fu5 neoi5 si6 mou6 wai2 jyun4 wui2; Misja i zakres uprawnień, Komisja ds. Kobiet], https://www.women.gov.hk/ tc/aboutus/mission.html (dostęp: 2.04.2019).

申請資格, 在職家庭津貼計劃(職津計劃), [san1 cing2 zi1 gaak3, zoi6 zik1 gaa1 ting4 zeon1 tip3 gai3 waak6 (zik1 zeon1 gai3 waak6); Kryteria kwalifikowalności do składania wniosku, Program dopłat dla rodzin pracujących (plan zatrudnienia)], https:/www.wfsfaa.gov.hk/wfao/tc/ eligibility.htm (dostęp: 1.04.2019).

社會保障 > 簡介及目標, [se5 wui2 bou2 zoeng3 > gaan2 gaai3 kap6 muk6 biu1; Zabezpieczenie społeczne> Wprowadzenie i cele], https://www.swd.gov.hk/tc/index/site_pubsvc/page_socsecu/ sub_introducti/ (dostęp: 6.04.2019).

社會保障上訴委員會, [se5 wui2 bou2 zoeng3 soeng5 sou3 wai2 jyun4 wui2; Rada Odwoławcza ds. Ubezpieczeń Społecznych], https://www.swd.gov.hk/tc/index/site_pubsvc/page_socsecu/ sub_ssappeal/ (dostęp: 6.04.2019).

社會福利, 香港年報, [se5 wui2 fuk1 lei6, hoeng1 gong2 nin4 bou3; Opieka społeczna, Raport roczny, Hongkong] za lata 2007-2018.

社會福利, 香港政府一站通, 2018年4月, [se5 wui2 fuk1 lei6, hoeng1 gong2 zing3 fu2 jat1 zaam6 tung1, 2018 nin4 4 jyut6; Opieka społeczna, Rząd Hongkongu GovHK, kwiecień 2018 r.].

Sprawozdanie dla Parlamentu Europejskiego i Rady. Specjalny Region Administracyjny Hongkong: sprawozdanie roczne za 2017 r., Bruksela, dnia 24.4.2018 r., JOIN(2018) 7 final (8316/18 ur DGC 1B PL).

津貼金額,在職家庭津貼計劃(職津計劃), [zeon1 tip3 gam1 ngaak6,zoi6 zik1 gaa1 ting4 zeon1 tip3 gai3 waak6 (zik1 zeon1 gai3 waak6); Kwota zasiłku (wysokość dodatku), Program dopłat dla rodzin pracujących (plan zatrudnienia)] https://www.wfsfaa.gov.hk/wfao/tc/amount.htm (dostęp: 1.04.2019).

自力更生支援計劃, [zi6 lik6 gang3 saang1 zi1 wun4 gai3 waak6; Plan wsparcia samodzielności], https://www.swd.gov.hk/tc/index/site_pubsvc/page_socsecu/sub_supportfor/(dostęp: 6.04.2019).

在職家庭及學生資助事務處,主頁, 歡迎辭, [zoi6 zik1 gaa1 ting4 kap6 hok6 saang1 zi1 zo6 si6 mou6 cyu3,zyu2 jip6, fun1 jing4 ci4; Rodzina pracująca i studenckie biuro pomocy finansowej, Strona główna, Mowa powitalna], https://www.wfsfaa.gov.hk/tc/index.htm (dostęp: 6.04.2019). 綜合社會保障援助(綜援)計劃, [zung1 hap6 se5 wui2 bou2 zoeng3 wun4 zo6 (zung1 wun4)gai3 waak6; Program kompleksowej pomocy społecznej (KPPS)], https://www.swd.gov.hk/tc/index/ site_pubsvc/page_socsecu/sub_comprehens/(dostęp: 6.04.2019).

綜援長者廣東及福建省養老計劃, [zung1 wun4 coeng4 ze2 gwong2 dung1 kap6 fuk1 gin3 saang2 joeng5 lou5 gai3 waak6; Emerytalny program KPPS dla seniorów w prowincji Guangdong i Fujian], https://www.swd.gov.hk/tc/index/site_pubsvc/page_socsecu/sub_portableco/ (dostęp: 6.04.2019). 